www.mdpi.com/journal/marinedrugs

Article

\title{
Nine New and Five Known Polyketides Derived from a Deep Sea-Sourced Aspergillus sp. 16-02-1
}

\author{
Xiu-Wen Chen ${ }^{1,2,3, \dagger}$, Chang-Wei Li ${ }^{1, \dagger}$, Cheng-Bin Cui ${ }^{1, *}$, Wei Hua ${ }^{1}$, Tian-Jiao Zhu ${ }^{4}$ and \\ Qian-Qun Gu ${ }^{4}$
}

1 Beijing Institute of Pharmacology and Toxicology, Beijing 100850, China;

E-Mails: chenxiuwen2010@126.com (X.-W.C.); sdrlcw@126.com (C.-W.L.); huawei0917@outlook.com (W.H.)

2 College of Pharmacy, Guangxi Medical University, Nanning 530021, China

3 Department of Biology and Chemistry, Hunan University of Science and Engineering, Yongzhou 425100, China

4 Key Laboratory of Marine Drugs, Chinese Ministry of Education, Institute of Marine Drugs and Food, School of Medicine and Pharmacy, Ocean University of China, Qingdao 266003, China; E-Mails: zhutj@ouc.edu.cn (T.-J.Z.); guqianq@ouc.edu.cn (Q.-Q.G.)

$\dagger$ These authors contributed equally to this work.

* Author to whom correspondence should be addressed; E-Mail: cuicb@126.com;

Tel./Fax: +86-10-6821-1656.

Received: 24 March 2014; in revised form: 12 April 2014 / Accepted: 16 April 2014 /

Published: 27 May 2014

\begin{abstract}
Nine new $\mathrm{C}_{9}$ polyketides, named aspiketolactonol (1), aspilactonols A-F (2-7), aspyronol (9) and epiaspinonediol (11), were isolated together with five known polyketides, $(S)$-2-(2'-hydroxyethyl)-4-methyl- $\gamma$-butyrolactone (8), dihydroaspyrone (10), aspinotriol A (12), aspinotriol B (13) and chaetoquadrin F (14), from the secondary metabolites of an Aspergillus sp. 16-02-1 that was isolated from a deep-sea sediment sample. Structures of the new compounds, including their absolute configurations, were determined by spectroscopic methods, especially the 2D NMR, circular dichroism (CD), $\mathrm{Mo}_{2}$-induced CD and Mosher's ${ }^{1}$ H NMR analyses. Compound $\mathbf{8}$ was isolated from natural sources for the first time, and the possible biosynthetic pathways for 1-14 were also proposed and discussed. Compounds 1-14 inhibited human cancer cell lines, K562, HL-60, HeLa and BGC-823, to varying extents.
\end{abstract}


Keywords: Aspergillus sp. 16-02-1; fungal strain from deep sea sediment; aspiketolactonol; aspilactonol; aspyronol; lactone; epiaspinonediol; polyketide; structure; cytotoxicity

\section{Introduction}

In recent five years from 2008 to 2012, more than 5500 new compounds have been discovered from marine natural products [1-5]. Marine microorganisms, especially the marine fungi, are increasingly a major focus of marine natural product researches, providing a lot of structurally novel and bioactive compounds [1-10]. Fungi from marine environments have great potential to be a rich source of drug leads [6-10] and over 30 compounds derived from marine microbes are currently in preclinical studies or clinical trials [10,11]. Recently, microorganisms from deep-sea habitats, including the hydrothermal vents, have become an interesting and newly emerging source of novel bioactive compounds $[3,8,9,12]$. Although a handful of reports described new compounds from fungi derived from these habitats [9], relevant researches have attracted considerable, growing research interest [13-16].

During the ongoing search for new bioactive natural products from marine-sourced fungi, we have evaluated cytotoxicity and antifungal activities for 16 fungal strains from deep-sea habitats, and found that an Aspergillus sp. 16-02-1 produced metabolites with both cytotoxic and antifungal activities. The strain Aspergillus sp. 16-02-1 was isolated from a deep-sea sediment sample that was collected at a Lau Basin hydrothermal vent (depth $2255 \mathrm{~m}$, temperature $114^{\circ} \mathrm{C}$ ) in southwest Pacific. We previously reported 8 known metabolites from this strain by a liquid fermentation [17]. In a continuation, we re-fermented this strain using solid-substrate fermentation medium and obtained nine new (1-7, 9 and 11) and five known (8, 10, and 12-14) polyketides shown in Figure 1. We report herein the isolation, structure elucidation, and cytotoxicity evaluation of these compounds in detail.

Figure 1. Structures of 1-14.

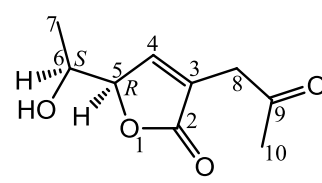

1<smiles>CC1C=C(CCO)C(=O)O1</smiles>

8<smiles>CC(O)CCC1=C[C@H](C)OC1=O</smiles>

2

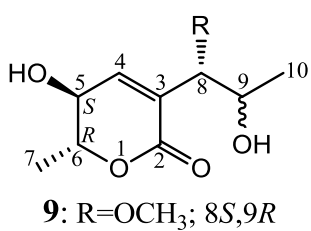
10: $\mathrm{R}=\mathrm{H} ; 9 S$

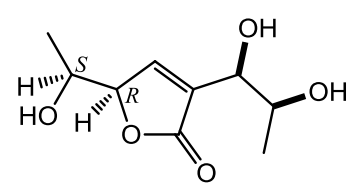

3: $8 S, 9 R ; \mathbf{4}: 8 R, 9 S$<smiles>C[14C](O)C=C(C=CC(=O)I)CO</smiles>

11

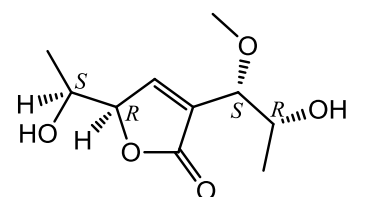

5<smiles>C[13C](O)=C(/C=C/[C@H](O)I)CO</smiles>

12: $2 S ; 13: 2 R$<smiles>C[C@H](O)[C@@H]1C=C(C[C@@H](C)O)C(=O)O1</smiles>

6/7: $9 R^{*} / 9 S^{*}$<smiles>Cc1c(O)cc(C[C@H](C)O)oc1=O</smiles>

14 


\section{Results and Discussion}

\subsection{Fermentation, Isolation, and Identification of Known Compounds}

The fermentation and extraction of Aspergillus sp. 16-02-1 gave an ethyl acetate (EtOAc) extract that inhibited K562 cells with an inhibition rate (IR\%) of $76.8 \%$ at $100 \mu \mathrm{g} / \mathrm{mL}$. The repeated column chromatography of the EtOAc extract coupled with HPLC purification afforded 14 metabolites 1-14 (Figure 1). Among them, structures of the nine new compounds 1-7, 9 and 11 were elucidated by modern spectroscopic methods, and named aspiketolactonol (1), aspilactonols A-F (2-7), aspyronol (9) and epiaspinonediol (11). The five known compounds 8, 10, and 12-14 were identified as (S)-2-(2'-hydroxyethyl)-4-methyl- $\gamma$-butyrolactone (8) [18], dihydroaspyrone (10) [19], aspinotriol A (12) [19], aspinotriol B (13) [19] and chaetoquadrin F (14) [20] by the physicochemical and spectroscopic data.

\subsection{Structure Determination of New Compounds}

Aspiketolactonol (1), colorless oil (from $\mathrm{MeOH}$ ), $[\alpha]_{\mathrm{D}}^{25}+10.5$ (c $0.12, \mathrm{MeOH}$ ), was assigned the molecular formula $\mathrm{C}_{9} \mathrm{H}_{12} \mathrm{O}_{4}$ by HRESIMS (measured $185.0811[\mathrm{M}+\mathrm{H}]^{+}$, calculated for $\mathrm{C}_{9} \mathrm{H}_{13} \mathrm{O}_{4}[\mathrm{M}+\mathrm{H}]^{+}$ 185.0814). It showed end UV absorption, and the IR spectrum showed the absorptions due to $\mathrm{OH}\left(3417 \mathrm{~cm}^{-1}\right), \mathrm{CH}_{3} / \mathrm{CH}_{2}\left(2980,2938,2906,1422\right.$ and $\left.1360 \mathrm{~cm}^{-1}\right), \alpha, \beta$-unsaturated $\gamma$-lactone (1752 and $\left.1656 \mathrm{~cm}^{-1}\right)$ [21,22] and keto carbonyl $\left(1722 \mathrm{~cm}^{-1}\right)$ groups. The olefinic proton and carbon signals at the lower field $\left(\delta_{\mathrm{H}} 7.43\right.$ and $\left.\delta_{\mathrm{C}} 149.4\right)$ [22] of ${ }^{1} \mathrm{H}$ and ${ }^{13} \mathrm{C}$ NMR spectra (Tables 1 and 2) and the ester carbonyl carbon signal at $\delta_{\mathrm{C}} 173.5$ in the ${ }^{13} \mathrm{C}$ NMR spectrum (Table 2) supported the presence of the $\alpha, \beta$-unsaturated $\gamma$-lactone moiety. The carbonyl carbon signal at $\delta_{\mathrm{C}} 203.6$ in the ${ }^{13} \mathrm{C} \mathrm{NMR}$ spectrum further supported the presence of one keto carbonyl in 1. Interpretation of the ${ }^{1} \mathrm{H}-{ }^{1} \mathrm{H}$ COSY, HMQC and HMBC data (Table S1 in the Supplementary Information) established the planar structure. The structural part related to the ${ }^{1} \mathrm{H}$ spin system, C-7-C-4(via quaternary $\mathrm{sp}^{2} \mathrm{C}-3$ ) $-\mathrm{C}-8$, was deduced from the ${ }^{1} \mathrm{H}-{ }^{1} \mathrm{H}$ COSY and HMQC data, including the allylic coupling between $\mathrm{H}-4 / \mathrm{H}_{2}-8$, which was confirmed by the HMBC correlations of $\mathrm{H}-4, \mathrm{H}-5$ and $\mathrm{H}_{2}-8$ with $\mathrm{C}-3$. The acetyl group that consisted of the C-9 keto carbonyl and the C-10 methyl was linked to C-8 by the HMBCs on $\mathrm{H}_{2}-8 / \mathrm{C}-9, \mathrm{H}_{3}-10 / \mathrm{C}-8$ and $\mathrm{H}_{3}-10 / \mathrm{C}-9$. The ester carbonyl carbon $\left(\mathrm{C}-2, \delta_{\mathrm{C}} 173.5\right)$ was linked to $\mathrm{C}-3$ by the HMBC correlations of $\mathrm{H}-4$ and $\mathrm{H}_{2}-8$ with $\mathrm{C}-2$. Then, $\mathrm{C}-2$ was further linked to $\mathrm{C}-5$ by an ester linkage to form the $\alpha, \beta$-unsaturated $\gamma$-lactone ring according to the IR absorption at $1752 \mathrm{~cm}^{-1}$.

The stereochemistry of 1 was determined as follows. The coupling of H-5/H-6 (4.7 Hz) indicated the erythro relative configuration of 5,6-diol in $\mathbf{1}$. The couplings of the same protons are larger than $4 \mathrm{~Hz}$ in erythro isomers but smaller than $2 \mathrm{~Hz}$ in threo isomers in the $\alpha, \beta$-unsaturated $\gamma$-lactones [23-25]. The CD of the $\alpha, \beta$-unsaturated $\gamma$-lactone rings with a chiral $\gamma$-carbon shows Cotton effects associated with the $\pi \rightarrow \pi^{*}$ transition in the region 200-235 nm [26] and the $\mathrm{n} \rightarrow \pi^{*}$ transition in the region 235-270 nm [26-29]. Generally the $\pi \rightarrow \pi^{*}$ Cotton effect is decisive to assign the absolute configuration of the $\alpha, \beta$-unsaturated $\gamma$-lactone ring because of the easy influence of the $n \rightarrow \pi^{*}$ Cotton effect by external asymmetry [26,27]. Compound 1 showed positive $\pi \rightarrow \pi^{*}$ Cotton effect at $233 \mathrm{~nm}$ (Figure 2), indicating the $R$ absolute configuration at C-5 [26,27]. The absolute configuration at C-6 was thus assigned to be $S$ according to the erythro relative configuration of 5,6-diol in $\mathbf{1}$. 
Figure 2. Circular dichroism (CD) spectra of compounds 1-10 in $\mathrm{MeOH}$.
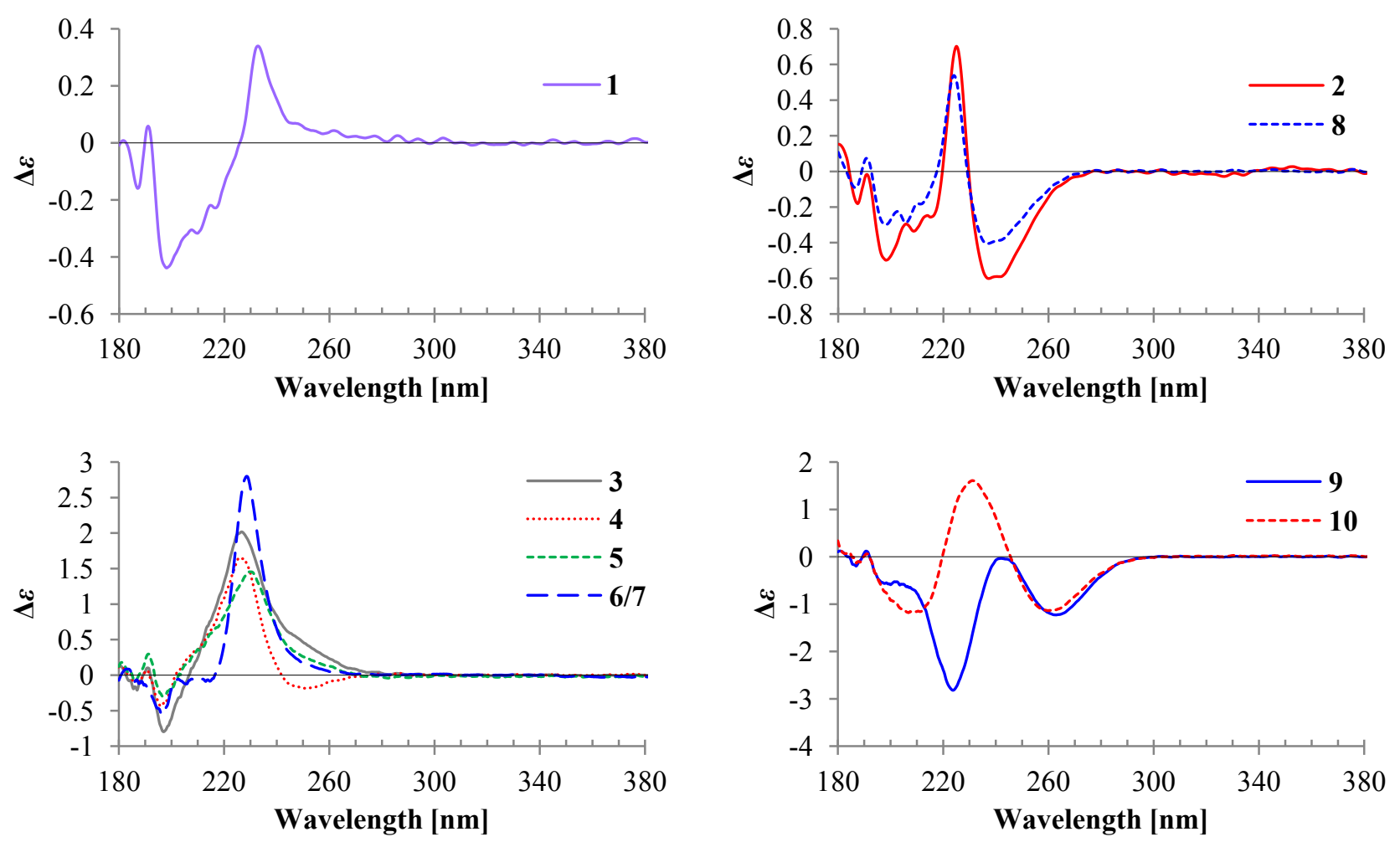

Aspilactonol A (2), colorless oil $(\mathrm{MeOH}),[\alpha]_{\mathrm{D}}^{25}+24.6(c$ 0.23, MeOH), was assigned the molecular composition $\mathrm{C}_{9} \mathrm{H}_{14} \mathrm{O}_{3}$ by HRESIMS (measured $171.1015[\mathrm{M}+\mathrm{H}]^{+}$, calculated for $\mathrm{C}_{9} \mathrm{H}_{15} \mathrm{O}_{3}[\mathrm{M}+\mathrm{H}]^{+}$ 171.1021). The IR spectrum showed absorptions ascribable to the $\mathrm{OH}, \mathrm{CH}_{3} / \mathrm{CH}_{2}$ and $\alpha, \beta$-unsaturated $\gamma$-lactone groups (Experimental Section). Similar to 1, the olefinic proton and carbon signals at the lower field $\left(\delta_{\mathrm{H}} 7.04, \mathrm{H}-4\right.$ and $\left.\delta_{\mathrm{C}} 149.8, \mathrm{C}-4\right)$ [22] of the ${ }^{1} \mathrm{H}$ and ${ }^{13} \mathrm{C}$ NMR spectra (Tables 1 and 2) together with the ester carbonyl $\left(\delta_{\mathrm{C}} 174.3 \mathrm{C}-2\right)$ and the $\mathrm{sp}^{2}$ carbon $\left(\delta_{\mathrm{C}} 134.0, \mathrm{C}-3\right)$ signals in the ${ }^{13} \mathrm{C}$ NMR spectrum (Table 2) supported the presence of the $\alpha, \beta$-unsaturated $\gamma$-lactone moiety in 2 . Then, the planar structure was established by interpretation of the ${ }^{1} \mathrm{H}-{ }^{1} \mathrm{H}$ COSY, HMQC and HMBC data (Table S2 in the Supplementary Information). The carbon backbone chain related to the ${ }^{1} \mathrm{H}$ spin system, C-6-C-4(via quaternary $\mathrm{sp}^{2} \mathrm{C}-3$ ) $-\mathrm{C}-7-\mathrm{C}-10$, could be derived from the ${ }^{1} \mathrm{H}-{ }^{1} \mathrm{H}$ COSY and HMQC data (Table S2 in the Supplementary Information), including the allylic coupling between $\mathrm{H}-4 / \mathrm{H}_{2}-7$, which was confirmed by the HMBC correlations of $\mathrm{H}-4, \mathrm{H}-5, \mathrm{H}_{2}-7$ and $\mathrm{H}_{2}-8$ with $\mathrm{C}-3$. The carbonyl carbon C-2 $\left(\delta_{\mathrm{C}} 174.3\right)$ was linked to C-5 and C-3 by the HMBC correlations between H-5/C-2, $\mathrm{H}-4 / \mathrm{C}-2$ and $\mathrm{H}_{2}-7 / \mathrm{C}-2$ to form the $\alpha, \beta$-unsaturated $\gamma$-lactone ring with the ester linkage between $\mathrm{C}-5$ and $\mathrm{C}-2$. 
Table 1. $400 \mathrm{MHz}{ }^{1} \mathrm{H}$ NMR data of compounds $1-7\left(\delta_{\mathrm{H}}, J \text { in } \mathrm{Hz}\right)^{\text {a }}$.

\begin{tabular}{ccccccc}
\hline Proton & $\mathbf{1}$ & $\mathbf{2}$ & $\mathbf{3}$ & $\mathbf{4}$ & $\mathbf{5}$ & $\mathbf{6} / 7^{\mathbf{b}}$ \\
\hline 4 & $7.43 \mathrm{q}(1.4)$ & $7.04 \mathrm{q}(1.6)$ & $7.54 \mathrm{dd}$ & $7.56 \mathrm{dd}$ & $7.55 \mathrm{dd}$ & $7.41 / 7.32, \mathrm{dd}$ \\
& & & $(3.0,1.5)$ & $(2.8,1.6)$ & $(1.5,0.9)$ & $(2.8,1.6)$ \\
5 & $4.88 \mathrm{dq}$ & $5.01 \mathrm{qq}(6.9,1.6)$ & $4.96-4.92 \mathrm{~m}$ & $4.92 \mathrm{ddd}$ & $4.98 \mathrm{dt}$ & $4.87 \mathrm{dd}$ \\
& $(4.7,1.4)$ & & & $(5.0,2.8,1.6)$ & $(4.5,1.5)$ & $(4.4,2.8,1.6)$ \\
6 & $4.02 \mathrm{qd}$ & $1.413 \mathrm{H} \mathrm{d}(6.9)$ & $3.95 \mathrm{qd}$ & $3.92 \mathrm{qd}$ & $3.97 \mathrm{qd}$ & $3.92 \mathrm{qd}$ \\
& $(6.5,4.7)$ & & $(6.5,4.6)$ & $(6.4,5.0)$ & $(6.4,4.5)$ & $(6.4,4.4)$ \\
7 & $1.283 \mathrm{H} \mathrm{d}$ & $2.28-2.572 \mathrm{H} \mathrm{m}$ & $1.253 \mathrm{H} \mathrm{d}$ & $1.263 \mathrm{H} \mathrm{d}(6.4)$ & $1.263 \mathrm{H} \mathrm{d} \mathrm{(6.4)}$ & $1.253 \mathrm{H} \mathrm{d}$ \\
& $(6.5)$ & & $(6.5)$ & & & $(6.4)$ \\
8 & $3.46 \mathrm{H} \mathrm{t}$ & $1.60-1.782 \mathrm{H} \mathrm{m}$ & $4.36 \mathrm{dt}$ & $4.34 \mathrm{brd}(4.9)$ & $3.96 \mathrm{brd} \mathrm{(4.7)}$ & $2.412 \mathrm{H} \mathrm{br} \mathrm{d}$ \\
& $(1.4)$ & & $(4.6,1.5)$ & & & $(6.2)$ \\
9 & - & $3.80 \mathrm{sext}(6.4)$ & $4.03 \mathrm{qd}$ & $3.99 \mathrm{qd}$ & $4.04 \mathrm{qd}$ & $4.02 \mathrm{sext}(6.2)$ \\
& & & $(6.4,4.6)$ & $(6.4,4.9)$ & $(6.4,4.7)$ & \\
10 & $2.243 \mathrm{H} \mathrm{s}$ & $1.213 \mathrm{H} \mathrm{d}(6.4)$ & $1.123 \mathrm{H} \mathrm{d}$ & $1.123 \mathrm{H} \mathrm{d}(6.4)$ & $1.123 \mathrm{H} \mathrm{d} \mathrm{(6.4)}$ & $1.193 \mathrm{H} \mathrm{d}$ \\
& & & $(6.4)$ & & & $(6.2)$ \\
$\mathrm{OCH}_{3}$ & - & - & - & - & $3.353 \mathrm{H} \mathrm{s}$ & - \\
\hline
\end{tabular}

${ }^{a}$ Data were taken in $\mathrm{CDCl}_{3}$ for $\mathbf{1 - 2}$ and in $\mathrm{CD}_{3} \mathrm{OD}$ for $\mathbf{3}-\mathbf{7}$, and the $\delta_{\mathrm{H}}$ values were recorded using solvent signals $\left(\mathrm{CDCl}_{3}: \delta_{\mathrm{H}} 7.26\right.$ for 1-2; $\mathrm{CD}_{3} \mathrm{OD}: \delta_{\mathrm{H}} 3.31$ for 3-7) as references. Signal assignments were based on the results of ${ }^{1} \mathrm{H}-{ }^{1} \mathrm{H}$ COSY, HMQC and HMBC experiments. ${ }^{b}$ A pair of $\mathrm{H}-4$ signals in an approximate 1:1 ratio corresponded to the $1: 1$ mixture of $6 / 7$, the isomers at C-9.

Table 2. $100 \mathrm{MHz}{ }^{13} \mathrm{C}$ NMR data of compounds $1-7\left(\delta_{\mathrm{C}}\right.$, multiplicity ${ }^{\mathrm{a}}$.

\begin{tabular}{ccccccc}
\hline Position & $\mathbf{1}$ & $\mathbf{2}$ & $\mathbf{3}$ & $\mathbf{4}$ & $\mathbf{5}$ & $\mathbf{6} / \mathbf{7}^{\mathbf{b}}$ \\
\hline 2 & $173.5 \mathrm{~s}$ & $174.3 \mathrm{~s}$ & $174.5 \mathrm{~s}$ & $174.5 \mathrm{~s}$ & $174.6 \mathrm{~s}$ & $176.25 \mathrm{~s} / 176.18 \mathrm{~s}$ \\
3 & $128.2 \mathrm{~s}$ & $134.0 \mathrm{~s}$ & $136.9 \mathrm{~s}$ & $137.0 \mathrm{~s}$ & $133.9 \mathrm{~s}$ & $133.08 \mathrm{~s} / 133.04 \mathrm{~s}$ \\
4 & $149.4 \mathrm{~d}$ & $149.8 \mathrm{~d}$ & $150.3 \mathrm{~d}$ & $150.5 \mathrm{~d}$ & $152.0 \mathrm{~d}$ & $150.49 \mathrm{~d} / 150.03 \mathrm{~d}$ \\
5 & $85.5 \mathrm{~d}$ & $77.8 \mathrm{~d}$ & $87.1 \mathrm{~d}$ & $87.0 \mathrm{~d}$ & $87.4 \mathrm{~d}$ & $86.85 \mathrm{~d} / 86.82 \mathrm{~d}$ \\
6 & $67.8 \mathrm{~d}$ & $19.3 \mathrm{q}$ & $68.5 \mathrm{~d}$ & $68.6 \mathrm{~d}$ & $68.5 \mathrm{~d}$ & $68.57 \mathrm{~d} / 68.33 \mathrm{~d}$ \\
7 & $18.9 \mathrm{q}$ & $21.6 \mathrm{t}$ & $19.0 \mathrm{q}$ & $19.1 \mathrm{q}$ & $19.0 \mathrm{q}$ & $19.15 \mathrm{q} / 19.02 \mathrm{q}$ \\
8 & $39.1 \mathrm{t}$ & $37.2 \mathrm{t}$ & $71.7 \mathrm{~d}$ & $71.7 \mathrm{~d}$ & $81.6 \mathrm{~d}$ & $35.72 \mathrm{t} / 35.67 \mathrm{t}$ \\
9 & $203.6 \mathrm{~s}$ & $67.0 \mathrm{~d}$ & $69.8 \mathrm{~d}$ & $70.1 \mathrm{~d}$ & $69.0 \mathrm{~d}$ & $66.49 \mathrm{~d} / 66.47 \mathrm{~d}$ \\
10 & $30.3 \mathrm{q}$ & $23.6 \mathrm{q}$ & $17.7 \mathrm{q}$ & $17.9 \mathrm{q}$ & $18.2 \mathrm{q}$ & $23.26 \mathrm{q}$ \\
$\mathrm{OCH}_{3}$ & - & - & - & - & $58.1 \mathrm{q}$ & - \\
\hline
\end{tabular}

${ }^{\text {a }}$ Data were taken in $\mathrm{CDCl}_{3}$ for $\mathbf{1}-\mathbf{2}$ and in $\mathrm{CD}_{3} \mathrm{OD}$ for $\mathbf{3}-\mathbf{7}$, and the $\delta_{\mathrm{C}}$ values were recorded using solvent signals $\left(\mathrm{CDCl}_{3}: \delta_{\mathrm{C}} 77.16\right.$ for $\mathbf{1}-\mathbf{2} ; \mathrm{CD}_{3} \mathrm{OD}$ : $\delta_{\mathrm{C}} 49.00$ for 3-7) as references. Signal assignments were based on the results of ${ }^{1} \mathrm{H}-{ }^{1} \mathrm{H}$ COSY, HMQC and HMBC experiments. ${ }^{b}$ Pairs of C-2-C-9 signals in an approximate $1: 1$ ratio corresponded to the $1: 1$ mixture of $6 / 7$, the isomers at $C-9$.

The absolute configuration at C-5 was assigned to be $S$ by the positive $\pi \rightarrow \pi^{*}$ Cotton effect at $225 \mathrm{~nm}$ and the negative $\mathrm{n} \rightarrow \pi^{*}$ Cotton effect around $239 \mathrm{~nm}$ (Figure 2) [26,27]. The absolute configuration at C-9 was assigned by the modified Mosher's method [30,31]. Treatment of 2 with $(S)$ - $\alpha$-methoxy- $\alpha$ trifluoromethyl phenylacetyl chloride $[(S)$-MTPA-Cl] and $(R)$-MTPA-Cl gave $(S)$-MTPA ester (2a) and $(R)$-MTPA ester (2b), respectively. The $\Delta \delta\left(\delta_{\mathrm{S}}-\delta_{\mathrm{R}}\right)$ values of relevant proton signals from $\mathbf{2 a}$ and 2b established the $S$ absolute configuration of C-9 in $\mathbf{2}$ (Figure 3). 
Figure 3. The $\Delta \delta\left(\delta_{\mathrm{S}}-\delta_{\mathrm{R}}\right)$ values from the $(S)$ - and $(R)$-MTPA esters of $\mathbf{2}, \mathbf{5}$ and $\mathbf{9}$.

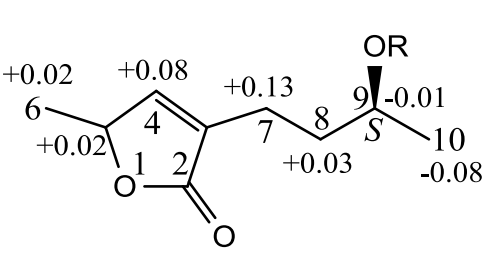

2a: $\mathrm{R}=(S)$-MTPA

2b: $\mathrm{R}=(R)$-MTPA

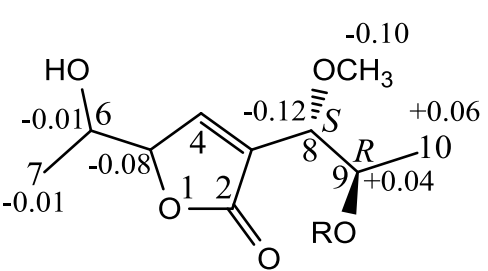

5a: $\mathrm{R}=(S)$-MTPA

5b: $\mathrm{R}=(R)$-MTPA

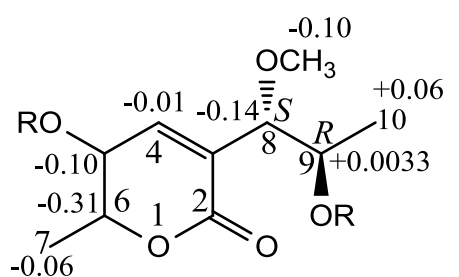

9a: $\mathrm{R}=(S)-\mathrm{MTPA}$

9b: $\mathrm{R}=(R)-\mathrm{MTPA}$

Aspilactonol B (3), $[\alpha]_{\mathrm{D}}^{25}+27.2(c 0.32, \mathrm{MeOH})$, and aspilactonol C (4), $[\alpha]_{\mathrm{D}}^{25}+34.5(c 0.41, \mathrm{MeOH})$, colorless oils $(\mathrm{MeOH})$, were assigned the molecular composition $\mathrm{C}_{9} \mathrm{H}_{14} \mathrm{O}_{5}$ by HRESIMS (measured 203.0919 $[\mathrm{M}+\mathrm{H}]^{+}$for 3 and $203.0910[\mathrm{M}+\mathrm{H}]^{+}$for 4, calculated for $\mathrm{C}_{9} \mathrm{H}_{15} \mathrm{O}_{4}[\mathrm{M}+\mathrm{H}]^{+}$203.0919). Both they showed end UV absorptions, and similar to $\mathbf{1}$ and $\mathbf{2}$, their IR spectra revealed the presence of $\alpha, \beta$-unsaturated $\gamma$-lactone moieties (around 1740 and $1652 \mathrm{~cm}^{-1}$ ) [21,22]. This was supported by the lower field olefinic proton and carbon signals (around $\delta_{\mathrm{H}} 7.55, \mathrm{H}-4$; around $\delta_{\mathrm{C}} 150.4, \mathrm{C}-4$ ) [22] in the ${ }^{1} \mathrm{H}$ and ${ }^{13} \mathrm{C}$ NMR spectra (Tables 1 and 2$)$ and the ester carbonyl $\left(\delta_{\mathrm{C}} 174.5, \mathrm{C}-2\right)$ and the $\mathrm{sp}^{2}$ carbon (around $\delta_{\mathrm{C}}$ 137, C-3) signals in the ${ }^{13} \mathrm{C}$ NMR spectra (Table 2). Their IR spectra also indicated the presence of $\mathrm{OH}$ and $\mathrm{CH}_{3} / \mathrm{CH}_{2}$ groups, and the strong $\mathrm{OH}$ signals around $3384 \mathrm{~cm}^{-1}$ further revealed more $\mathrm{OH}$ groups in $\mathbf{3}$ and $\mathbf{4}$ than in $\mathbf{1}$ and $\mathbf{2}$ (the IR spectra in the Supplementary Information). Interpretation of the ${ }^{1} \mathrm{H}-{ }^{1} \mathrm{H}$ COSY and HMQC data (Tables S3 and S4 in the Supplementary Information) established the carbon backbone chain related to the proton spin system, C-7-C-4(via quaternary $\mathrm{sp}^{2} \mathrm{C}-3$ ) $-\mathrm{C}-8-\mathrm{C}-10$. The allylic couplings between $\mathrm{H}-4$ and H-8 in $\mathbf{3}$ and $\mathbf{4}$ indicated the connection of $\mathrm{C}-4$ and $\mathrm{C}-8$ via the quaternary $\mathrm{sp}^{2}$ carbon $\mathrm{C}-3$, and the $\mathrm{C}-3$ carbon was assigned by the HMBC correlations of H-4, H-5, H-8 and H-9 with C-3 (Tables S3 and S4 in the Supplementary Information). The C-2 carbonyl carbons in $\mathbf{3}$ and $\mathbf{4}$ were linked to $\mathrm{C}-5$ and $\mathrm{C}-3$ by the HMBC correlations between $\mathrm{H}-5 / \mathrm{C}-2, \mathrm{H}-4 / \mathrm{C}-2$ and $\mathrm{H}-8 / \mathrm{C}-2$ to form the $\alpha, \beta$-unsaturated $\gamma$-lactone rings with the ester linkage between $\mathrm{C}-5$ and $\mathrm{C}-2$.

The absolute configuration at C-5 in $\mathbf{3}$ and $\mathbf{4}$ was assigned both to be $R$ by the positive $\pi \rightarrow \pi^{*}$ Cotton effect around $226 \mathrm{~nm}$ in the CD of $\mathbf{3}$ and 4 (Figure 2) [26,27]. Because the coupling of H-5 and $\mathrm{H}-6(4.6 \mathrm{~Hz}$ for 3 and $5.0 \mathrm{~Hz}$ for 4$)$ indicated the erythro relative configuration of 5,6-diols in 3 and 4 [23-25], the absolute configuration at C-6 in $\mathbf{3}$ and $\mathbf{4}$ was also assigned both to be $S$. Thus, 3 and 4 should be stereoisomers at the vicinal diol methine carbons C-8/C-9. There are many reports recorded that the coupling of vicinal diol methine protons is generally lager than $6 \mathrm{~Hz}$ in threo isomers but smaller than $5 \mathrm{~Hz}$ in erythro isomers of the relevant compounds with a vicinal diol unit similar to the 8,9-diols in 3 and 4 [32-36]. The coupling of H-8 and H-9 (4.6 Hz for 3 and $4.9 \mathrm{~Hz}$ for 4 ) indicated the erythro relative configuration of the 8,9-diols in 3 and 4 [32-36]. The absolute configuration of the erythro-8,9-diols in $\mathbf{3}$ and $\mathbf{4}$ was determined by the dimolybdenum induced CD (ICD) analysis. In the ICDs by the Snatzke's method using dimolybdenum tetraacetate $\left(\mathrm{Mo}_{2}(\mathrm{OAc})_{4}\right)$ in DMSO [37,38], the $\mathrm{Mo}_{2}$-complex of 3 gave negative CD bands II (near $400 \mathrm{~nm}$ ) and IV (around $329 \mathrm{~nm}$ ), while the $\mathrm{Mo}_{2}$-comlex of 4 gave the positive bands II and IV (Figure 4). By the Snatzke's helicity rule, the sign of $\mathrm{O}-\mathrm{C}-\mathrm{C}-\mathrm{O}$ torsional angle in the favored conformation of the chiral $\mathrm{Mo}_{2}$-complexes determines the 
sign of the bands II and IV [37,38]. We have demonstrated that in the erythro-diols closely resembled 3 and 4, the conformation with an antiperiplanar orientation of the $\mathrm{OH}$ and methyl groups, $\mathrm{O}-\mathrm{C}-\mathrm{C}-\mathrm{CH}_{3}$, is favored conformation of the $\mathrm{Mo}_{2}$-complexes [39], as shown for 3 and $\mathbf{4}$ in Figure 4. Therefore, the absolute configuration at C-8 and C-9 in $\mathbf{3}$ and $\mathbf{4}$ could be assigned to be $8 S, 9 R$ for $\mathbf{3}$ and $8 R, 9 S$ for $\mathbf{4}$ on the basis of their band II and IV signs (Figure 4), respectively.

Figure 4. Induced CD (ICD) spectra from the $\mathrm{Mo}_{2}$-complexes of 3 and 4 in DMSO.
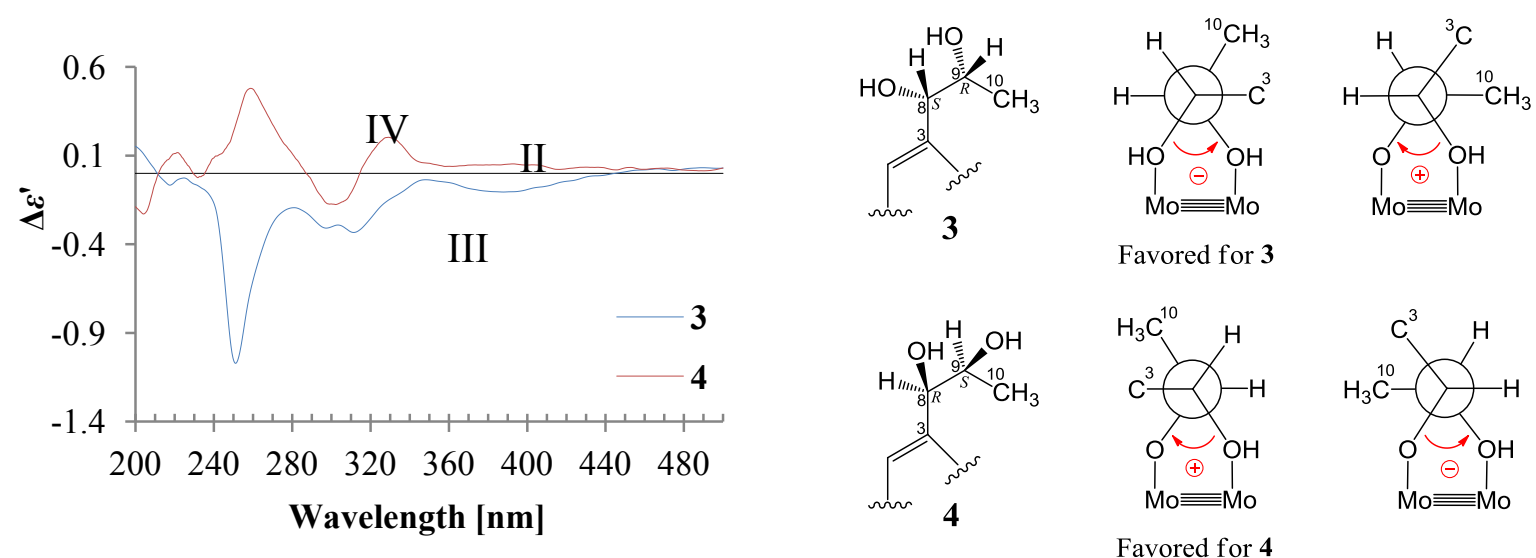

Aspilactonol D (5), colorless oil $(\mathrm{MeOH}),[\alpha]_{\mathrm{D}}^{25}-1.7(c 0.38, \mathrm{MeOH})$, was assigned the molecular formula $\mathrm{C}_{10} \mathrm{H}_{16} \mathrm{O}_{5}$ by HRESIMS (measured 217.1071 $[\mathrm{M}+\mathrm{H}]^{+}$, calculated for $\mathrm{C}_{10} \mathrm{H}_{17} \mathrm{O}_{5}[\mathrm{M}+\mathrm{H}]^{+}$ 217.1076), which had a $\mathrm{CH}_{2}$ composition more than in $\mathbf{3}$ and $\mathbf{4}$. It showed UV and IR absorptions similar to 3 and 4, and the IR absorptions revealed the presence of $\mathrm{OH}, \mathrm{CH}_{3} / \mathrm{CH}_{2}$ and $\alpha, \beta$-unsaturated $\gamma$-lactone groups (Experimental Section). The ${ }^{1} \mathrm{H}$ and ${ }^{13} \mathrm{C}$ NMR spectra of $\mathbf{5}$ in $\mathrm{CD}_{3} \mathrm{OD}$ showed signals similar to $\mathbf{3}$ and $\mathbf{4}$ except additional signals ascribable to an $O$-methyl group were detected (Tables 1 and 2). These NMR data indicated that 5 was an $O$-methylated. Analyses of the ${ }^{1} \mathrm{H}-{ }^{1} \mathrm{H}$ COSY, HMQC and HMBC spectra (Table S5 in the Supplementary Information) established its planar structure. The $\alpha, \beta$-unsaturated $\gamma$-lactone ring was confirmed by the HMBC correlations between H-5/C-2, H-4/C-2 and H-8/C-2. The $O$-methyl group was located at C- 8 by the HMBC correlations of the $O$-methyl protons with $\mathrm{C}-8$. The absolute configuration at $\mathrm{C}-5$ in 5 was assigned to be $R$ by the positive $\pi \rightarrow \pi^{*}$ Cotton effect at $231.5 \mathrm{~nm}$ in the CD spectrum (Figure 2) [26,27]. The coupling of H-5/H-6 (4.5 Hz) indicated the erythro relative configuration of 5,6-diol in 5 [23-25], and thus the absolute configuration at C-6 was assigned to be $S$. The $R$ absolute configuration of C-9 was determined by the modified Mosher's method [30,31] on the basis of the $\Delta \delta\left(\delta_{\mathrm{S}}-\delta_{\mathrm{R}}\right)$ values from the $(S)$ - and $(R)$-MTRA esters (Figure 3$)$. Since the coupling of $\mathrm{H}-8 / \mathrm{H}-9(4.7 \mathrm{~Hz})$ indicated the erythro relative configuration of 8,9-diol in 5 [32-36], the absolute configuration at C-8 was assigned to be $S$.

Aspilactonols E/F (6/7) were obtained as a mixture of epimers as a colorless oil from $\mathrm{MeOH}$, $[\alpha]_{\mathrm{D}}^{25}+78.1(c 1.00, \mathrm{MeOH})$, and the molecular formula $\mathrm{C}_{9} \mathrm{H}_{14} \mathrm{O}_{4}$ was determined by HRESIMS (measured $187.0967[\mathrm{M}+\mathrm{H}]^{+}$, calculated for $\mathrm{C}_{9} \mathrm{H}_{15} \mathrm{O}_{5}[\mathrm{M}+\mathrm{H}]^{+}$187.0970). In the UV spectrum, 6/7 showed the end absorption, and the IR spectrum showed absorptions due to the $\mathrm{OH}, \mathrm{CH}_{3} / \mathrm{CH}_{2}$ and $\alpha, \beta$-unsaturated $\gamma$-lactone groups (Experimental Section). The ${ }^{1} \mathrm{H}$ and ${ }^{13} \mathrm{C} \mathrm{NMR}$ spectra of $6 / 7$ in $\mathrm{CD}_{3} \mathrm{OD}$ showed signals similar to $\mathbf{3}-\mathbf{5}$, but they were characterized by the appearance of methylene signals instead of the signals from an oxygenated methine in 3-5 and an $O$-methyl group in $\mathbf{5}$ (Tables 1 
and 2). These NMR data indicated the same skeletal structures in 3-7. The appearance of the proton H-4 and the carbon signals except for the C-10 signal as pairs in an approximate 1:1 ratio indicated that 6/7 was a 1:1 mixture of stereoisomers. The planar structure of $6 / 7$ was deduced by the ${ }^{1} \mathrm{H}-{ }^{1} \mathrm{H}$ COSY, HMQC and HMBC data (Table S6 in the Supplementary Information), coupled with the IR absorptions at 1748 and $1651 \mathrm{~cm}^{-1}$ from an $\alpha, \beta$-unsaturated $\gamma$-lactone ring [21,22]. The absolute configuration at C-5 in 6/7 was assigned both to be $R$ by the strong positive $\pi \rightarrow \pi^{*}$ Cotton effect at $228.5 \mathrm{~nm}$ in the CD spectrum (Figure 2) [26,27]. Since the coupling of H-5/H-6 (4.4 Hz) indicated the erythro relative configuration of 5,6-diols in 6/7 [23-25], the absolute configuration at C-6 was assigned to be $S$ for both 6/7. Thus, 6/7 was a 1:1 mixture of epimers at C-9. Although a Doctor's Thesis has recorded the same planar structure of $\mathbf{6} / \mathbf{7}$, its stereochemistry was not elucidated [40]. We therefore named $6 / 7$ as aspilactonols $\mathrm{E} / \mathrm{F}$ as new compounds.

Aspyronol (9), colorless oil from $\mathrm{MeOH},[\alpha]_{\mathrm{D}}^{25}-41.6(c 0.22, \mathrm{MeOH})$, was assigned the molecular formula $\mathrm{C}_{10} \mathrm{H}_{16} \mathrm{O}_{5}$ by HRESIMS (measured $217.1073[\mathrm{M}+\mathrm{H}]^{+}$, calculated for $\mathrm{C}_{10} \mathrm{H}_{17} \mathrm{O}_{5}[\mathrm{M}+\mathrm{H}]^{+}$ 217.1076). It showed end UV absorption and the IR absorptions due to $\mathrm{OH}\left(3398 \mathrm{~cm}^{-1}\right), \mathrm{CH}_{3} / \mathrm{CH}_{2}$ (2982, 2938, 2905, 2835, 1451 and $\left.1384 \mathrm{~cm}^{-1}\right), \mathrm{C}=\mathrm{O}\left(1714 \mathrm{~cm}^{-1}\right)$ and $\mathrm{C}=\mathrm{C}\left(1649 \mathrm{~cm}^{-1}\right)$ groups. The ${ }^{1} \mathrm{H}$ and ${ }^{13} \mathrm{C}$ NMR spectra (Table 3 ) resembled those of dihydroaspyrone (10) except additional signals from a methoxy and an oxygenated methine groups were detected instead of the methylene signals in $\mathbf{1 0 .}$ There were also slight changes in several ${ }^{1} \mathrm{H}$ and ${ }^{13} \mathrm{C}$ signals. These NMR data suggested that 9 was a methoxylated derivative of 10, and this was confirmed by analysis of the ${ }^{1} \mathrm{H}-{ }^{1} \mathrm{H}$ COSY, HMQC and HMBC spectra (Table S7 in the Supplementary Information) to complete the planar structure. The carbon chain related to the proton spin system, C-7-C-4(via quaternary $\mathrm{sp}^{2} \mathrm{C}-3$ )-C-8-C-10, was deduced by interpretation of the ${ }^{1} \mathrm{H}-{ }^{1} \mathrm{H}$ COSY and HMQC data (Table S7 in the Supplementary Information). The allylic coupling between $\mathrm{H}-4$ and $\mathrm{H}-8$ suggested the connectivity of $\mathrm{C}-4$ and $\mathrm{C}-8$ via a quaternary $\mathrm{sp}^{2}$ carbon $\mathrm{C}-3$, and $\mathrm{C}-3$ was assigned by the HMBC correlations between $\mathrm{H}-8 / \mathrm{C}-3$ and $\mathrm{H}-9 / \mathrm{C}-3$. The $\mathrm{OCH}_{3}$ group was located at $\mathrm{C}-8$ by the $\mathrm{HMBC}$ of the methoxy protons with the carbon C-8. The carbonyl carbon C-2 was linked to C-3 by the HMBCs on H-4/C-2 and H-8/C-2. The ester linkage of the C-2 carbonyl was then linked to C- 6 to form a $\delta$-lactone ring by the coupling of $\mathrm{H}-5 / \mathrm{H}-6$ $(9.4 \mathrm{~Hz})$, which requires C-5/C-6 fixed in a six-membered ring with trans orientated $\mathrm{H}-5 / \mathrm{H}-6$. This was supported by the chemical shift of C-6, $\delta_{\mathrm{C}} 80.0$ in $\mathbf{9}$ and $\delta_{\mathrm{C}} 79.6$ in $\mathbf{1 0}$. The $R$ absolute configuration at C-9 was determined by the modified Mosher's method [30,31] on the basis of the $\Delta \delta\left(\delta_{\mathrm{S}}-\delta_{\mathrm{R}}\right)$ values from the $(S)$ - and $(R)$-MTRA esters of 9 (Figure 3), and the absolute configuration at C-8 was assigned to be $S$ because the coupling of $\mathrm{H}-8 / \mathrm{H}-9(4.6 \mathrm{~Hz})$ indicated the erythro relative configuration of 8,9-diol in 9 [32-36]. The absolute configuration at C-5 and C-6 in 9 was determined to be 5S,6R, the same as 10, according to the negative signs of the Cotton effects around $260 \mathrm{~nm}$ both from the chiral $\alpha, \beta$-unsaturated $\delta$-lactone units in 9 and $\mathbf{1 0}$ (Figure 2) [28]. This was also supported by the co-generation of 9 and 10 by the same Aspergillus sp. 16-02-1 strain from a biogenetic consideration. 
Table 3. $400 \mathrm{MHz}{ }^{1} \mathrm{H}$ and $100 \mathrm{MHz}{ }^{13} \mathrm{C}$ NMR data of $9{ }^{\mathrm{a}}$.

\begin{tabular}{|c|c|c|c|c|}
\hline \multirow{2}{*}{ NO. } & \multicolumn{2}{|c|}{ in $\mathrm{CD}_{3} \mathrm{OD}$} & \multicolumn{2}{|l|}{ in $\mathrm{CDCl}_{3}$} \\
\hline & $\boldsymbol{\delta}_{\mathrm{C}}$ & $\delta_{\mathrm{H}}(J$ in $\mathrm{Hz})$ & $\delta_{\mathrm{H}}(J$ in $\mathrm{Hz})$ & NOE \\
\hline 2 & $165.7 \mathrm{~s}$ & - & - & - \\
\hline 3 & $129.9 \mathrm{~s}$ & - & - & - \\
\hline 4 & $147.8 \mathrm{~d}$ & $6.78 \mathrm{t}(1.4)$ & $6.79 \mathrm{dd}(2.6,0.9)$ & \\
\hline 5 & $68.7 \mathrm{~d}$ & $4.21 \mathrm{dd}(9.4,1.4)$ & $4.25-4.20 \mathrm{~m}$ (masked by H-8) & $\mathrm{H}-7$ \\
\hline 6 & $80.0 \mathrm{~d}$ & $4.24 \mathrm{dq}(9.4,5.8)$ & $4.35 \mathrm{dq}(8.5,6.4)$ & \\
\hline 7 & $18.20 \mathrm{q}$ & $1.443 \mathrm{H} \mathrm{d}(5.8)$ & $1.483 \mathrm{H} \mathrm{d}(6.4)$ & $\mathrm{H}-5$ \\
\hline 8 & $83.5 \mathrm{~d}$ & $4.08 \mathrm{dd}(4.9,1.4)$ & 4.22 br d (4.6) & \\
\hline 9 & $70.1 \mathrm{~d}$ & $3.82 \mathrm{qd}(6.4,4.9)$ & $3.94 \mathrm{qd}(6.5,4.6)$ & \\
\hline 10 & $18.17 \mathrm{q}$ & $1.123 \mathrm{H} \mathrm{d}(6.4)$ & $1.103 \mathrm{H} \mathrm{d}(6.5)$ & \\
\hline $\mathrm{OCH}_{3}$ & $58.0 \mathrm{q}$ & $3.323 \mathrm{H} \mathrm{s}$ & $3.313 \mathrm{H} \mathrm{s}$ & \\
\hline
\end{tabular}

${ }^{\mathrm{a}}$ Chemical shifts were recorded in $\delta$ values using the solvent signals $\left(\mathrm{CDCl}_{3}: \delta_{\mathrm{H}} 7.26 ; \mathrm{CD}_{3} \mathrm{OD}: \delta_{\mathrm{H}} 3.31 / \delta_{\mathrm{C}} 49.00\right)$ as references, respectively. Signals were assigned on the basis of ${ }^{1} \mathrm{H}-{ }^{1} \mathrm{H} C O S Y, H M Q C$ and $\mathrm{HMBC}$ experiments.

Epiaspinonediol (11), yellow oil $(\mathrm{MeOH}),[\alpha]_{\mathrm{D}}^{25}-5.4(c 0.14, \mathrm{MeOH})$, was assigned the molecular formula $\mathrm{C}_{9} \mathrm{H}_{14} \mathrm{O}_{3}$ by HRESIMS (measured $193.0842[\mathrm{M}+\mathrm{Na}]^{+}$, calculated for $\mathrm{C}_{9} \mathrm{H}_{14} \mathrm{O}_{3} \mathrm{Na}[\mathrm{M}+\mathrm{Na}]^{+}$ 193.0841). The ${ }^{1} \mathrm{H}$ and ${ }^{13} \mathrm{C}$ NMR data of 11 in $\mathrm{CD}_{3} \mathrm{OD}$ were identical with those of aspinonediol in $\mathrm{CD}_{3} \mathrm{OD}$ [19], indicating the same planar structures of both compounds. Aspinonediol had the absolute configuration $7 S$ and showed $[\alpha]_{\mathrm{D}}^{24}+2.4(c 0.63, \mathrm{MeOH})$ [19]. In contrast, 11 showed the opposite optical rotation. Thus, the epiaspinonediol (11) was determined to be the epimer of aspinonediol at C-7 with the $7 R$ absolute configuration.

\subsection{Inhibitory Effects of 1-14 on Several Human Cancer Cell Lines}

Antitumor activities of 1-14 were tested by the MTT method using the human cancer K562, HL-60, HeLa, and BGC-823 cell lines. Compounds 1-14 inhibited some of the tested four cell lines and the IR\% values at $100 \mu \mathrm{g} / \mathrm{mL}$ are given below. 1: 11.7\% (HL-60); 2: 17.7\% (HL-60); 3: 22.2\% (HL-60); 4: 20.0\% (K562), 16.7\% (HL-60); 5: 20.0\% (HL-60), 13.2\% (BGC-823); 6/7: 14.1\% (K562), 13.4\% (HeLa); 8: 14.2\% (HL-60), 15.7\% (HeLa); 9: 27.9\% (K562), 67.2\% (HL-60), 14.0\% (HeLa); 10: 19.9\% (HL-60), 10.1\% (HeLa); 11: 79.7\% (K562); 72.5\% (HL-60), 14.9\% (HeLa), 21.8 (BGC-823); 12: 17.0\% (K562); 14.1\% (HeLa); 13: 20.3\% (K562), 39.4\% (HL-60), 12.3\% (HeLa), 15.7\% (BGC-823); 14: $13.5 \%(\mathrm{HeLa})$. The half-inhibitory concentration $\left(\mathrm{IC}_{50}\right)$ of 9 on HL-60 cells was determined to be $52.1 \mu \mathrm{g} / \mathrm{mL}(241.2 \mu \mathrm{M})$, and the $\mathrm{IC}_{50}$ for 11 on K562 and HL-60 cells to be $44.3 \mu \mathrm{g} / \mathrm{mL}(260.6 \mu \mathrm{M})$ and $32.8 \mu \mathrm{g} / \mathrm{mL}(192.9 \mu \mathrm{M})$, respectively. The positive control docetaxol inhibited these cell lines with the IR\% values of 55.6\% (K562), 49.9\% (HL-60), 45.1\% (HeLa), and 61.5\% (BGC-823) at $100 \mu \mathrm{g} / \mathrm{mL}$.

\subsection{Discussions}

Chemical investigation of a deep sea-sourced Aspergillus sp. 16-02-1 has resulted in the elucidation of 14 secondary metabolites $\mathbf{1}-\mathbf{1 4}$, including nine new (1-7, 9 and 11) and five known (8, 10, and 12-14) compounds, shown in Figure 1. Although compound $\mathbf{8}$ has been chemically prepared [18], it is the first time to report $\mathbf{8}$ from natural sources in present study. Structures of the new compounds, including 
their absolute configurations, were determined by extensive spectroscopic methods, especially the 2D NMR, CD, ICD and Mosher's ${ }^{1} \mathrm{H}$ NMR analyses. The determination of the absolute configuration of $\alpha, \beta$-unsaturated $\gamma$-lactone ring in 1-7 mainly relied on the $C D$ data. In most cases, a chiral $\alpha, \beta$-unsaturated $\gamma$-lactone ring gave both $\pi \rightarrow \pi^{*}$ and $n \rightarrow \pi^{*}$ Cotton effects with the opposite sign [26,27] in 200-235 nm and 235-270 nm regions, respectively [26-29]. However, usually the $\mathrm{n} \rightarrow \pi^{*}$ Cotton effect is weak and sometimes could not be observed [26,27] or even appeared with the same sign of the $\pi \rightarrow \pi^{*}$ Cotton effect [26]. The same is true of the case of 1-8. As shown in Figure 2, 2 and $\mathbf{8}$ gave both opposite $n \rightarrow \pi^{*}$ and $\pi \rightarrow \pi^{*}$ Cotton effects in similar magnitude and 4 also showed a weak $n \rightarrow \pi^{*}$ Cotton effect opposite to the $\pi \rightarrow \pi^{*}$ transition. However, the others did not give opposite $n \rightarrow \pi^{*}$ Cotton effect and rather they showed a weak CD curve with the same sign of the $\pi \rightarrow \pi^{*}$ Cotton effect in the $n \rightarrow \pi^{*}$ transition region (Figure 2). Since the easy influence of the $n \rightarrow \pi^{*}$ Cotton effect by the external asymmetry [26] and the decisive role of the $\pi \rightarrow \pi^{*}$ Cotton effect in absolute configuration assignment has been known [26,27], the absolute configurations of the $\alpha, \beta$-unsaturated $\gamma$-lactone rings in 1-7 could be assigned by the sign of their $\pi \rightarrow \pi^{*}$ Cotton effects shown in Figure 2.

Compounds 1-14 are all polyketides derived from a branched $C_{9}\left(1-7\right.$ and 9-14) or $C_{7}(8)$ carbon skeleton, and are derivatives of $\alpha, \beta$-unsaturated $\gamma$-lactone (1-8), $\alpha, \beta$-unsaturated $\delta$-lactone (9-10 and 14) or branched, acyclic linear $C_{8}$ carbon backbone chain with a conjugated diene group (11-13). The biosynthesis of aspyrone [41-46], asperlactone and isoasperlactone [44-46], and aspinonene [47], their structures were closely related to the compounds, 9-10/14, 1-8, and 11-13, respectively, have been exhaustively studied [41-47], and as indicated in Scheme 1 [46,47], it has been demonstrated that these metabolites derive from a common biosynthetic precursor, $\mathbf{I}-\mathbf{4}$, which originates from the intermediate $\mathbf{I}$, the ultimate product of polyketide synthesis (PKS), by post-PKS modifications (see in Scheme 1). Reduction of the aldehyde in I-4 into the primary alcohol give I-5, which undergo further modification to produce aspinonene [47], while oxidation of the aldehyde in I-4 into the carboxyl afford I-7, which switches the formation of aspyrone and asperlactone by nucleophilic attack of the carboxyl group on either site of the carbons in one of the two epoxide groups [44-47].

Relating to the above mentioned metabolites, plausible biosynthetic pathways for 1-7 and 9-13 are proposed in Scheme 1. Reduction of either one of the two epoxides in I-5, the precursor of aspinonene [47], coupled with hydration at either site of the other epoxide ring followed by dehydration, would give I-6 and compounds $\mathbf{1 2}$ and 13, which further underwent oxidation at C-2 to produce compound 11 and aspinonediol, the epimer of 11 at C-7 (Scheme 1). Aspyrone and asperlactone are proposed to be intermediates for 9-10 and 1/3-7. Reduction of the epoxide in aspyrone would give 10, and hydration at C-8 of the epoxide, followed by methylation, would afford 9 (Scheme 1). Reduction or hydration of the epoxide in asperlactone and further modification of the products by methylation, reduction or dehydration followed by keto-enol tautomerization, and oxidation/reduction reactions would produce $\mathbf{1}$ and $\mathbf{3}-\mathbf{7}$, as shown in Scheme 1. The $\gamma$-lactone $\mathbf{2}$ seems likely to be produced from the intermediate $\mathbf{I}-\mathbf{7}$. Reduction of the epoxides in $\mathbf{I}-\mathbf{7}$ coupled with double bond rearrangement, followed by lactonization of the product $\mathbf{I - 8}$, would give $\mathbf{2}$ (Scheme 1). 
Scheme 1. Plausible biosynthetic pathways of 1-7 and 9-13.

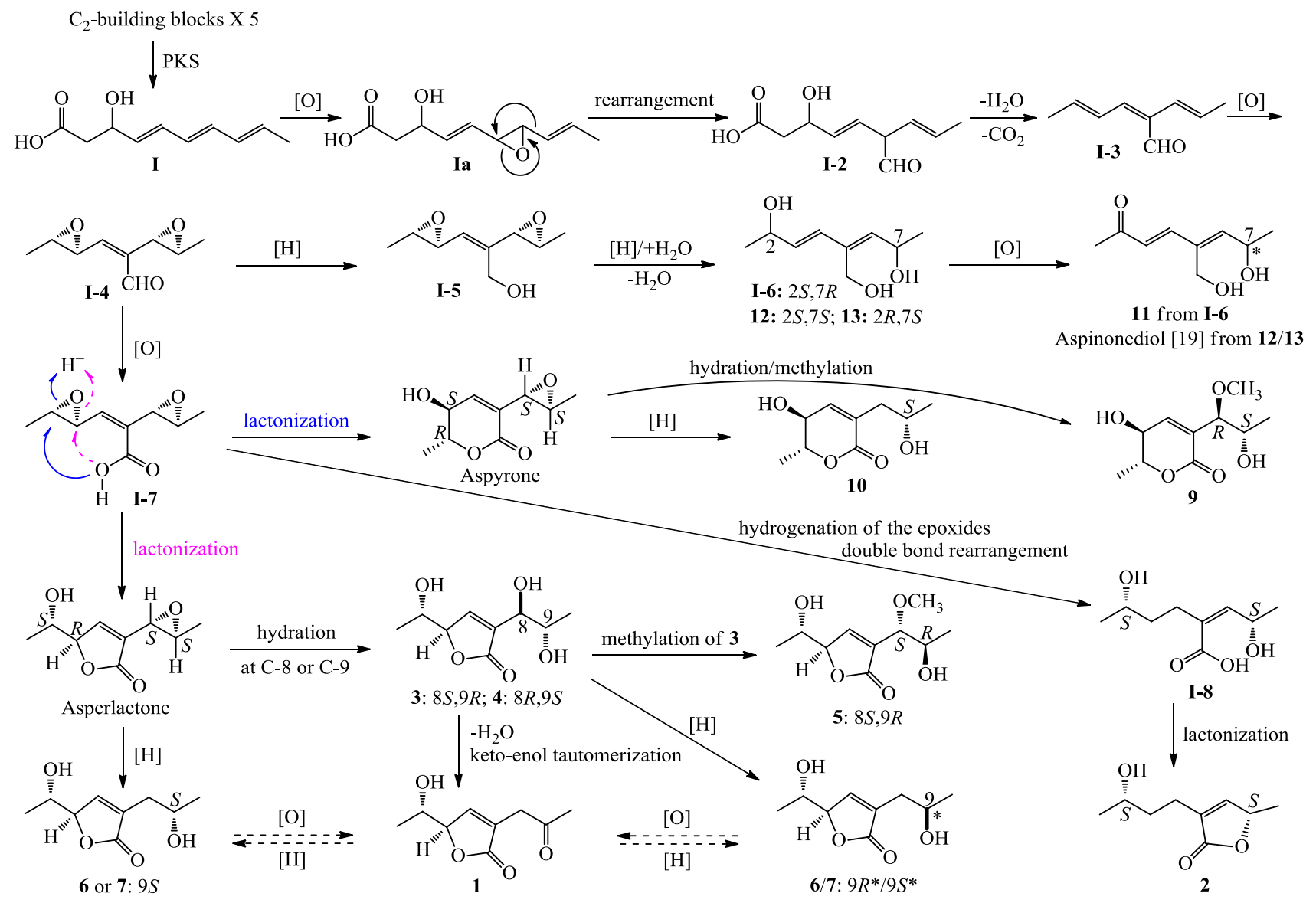

In view of the structural features of 1, 3-4 and 6-7, one of these compounds may probably form from some or other during extraction with EtOAc at the slightly acidic conditions by the acid-catalyzed chemical reactions artificially. In order to confirm whether this occurred in truth, each $0.3 \mathrm{mg}$ of the crude compound samples was dissolved in $0.2 \mathrm{~mL}$ water-saturated EtOAc in a $0.5 \mathrm{~mL}$ Eppendorf tube, capped the tube and kept at room temperature for 6 days, and then further treated at $50{ }^{\circ} \mathrm{C}$ for $16 \mathrm{~h}$. These treatment conditions simulated the extraction conditions (whole extraction was achieved within 4 days with a total of $12 \mathrm{~h}$ evaporating times at the temperature lower than $40{ }^{\circ} \mathrm{C}$ ). Then, the aqueous EtOAc was removed by blowing inside of the tube with nitrogen gas to dryness. The residue was dissolved in $\mathrm{MeOH}$ and then subjected to HPLC analysis. No any one of them was detected in other compound samples by the HPLC analysis (Figure S1 in the Supplementary Information), confirming that none of these compounds are artificial product formed from the others in the extraction conditions.

Differing from 1-7/9-13, they are all pentaketide derivatives as shown in Scheme 1, compound 8 seems likely to be a tetraketide derivative. A plausible pathway for the $\mathbf{8}$ biosynthesis is proposed in Scheme 2. A first intermediate in this pathway was proposed to be II, the ultimate tetraketide product of PKS, like the intermediate $\mathbf{I}$ in Scheme 1. Similar to the 1-7/9-13 biosynthesis from $\mathbf{I}$ as shown in Scheme 1, post-PKS modifications of II would give a key intermediate II-4, which underwent further modification would produce $\mathbf{8}$. 
Scheme 2. Plausible biosynthetic pathway of 8 .

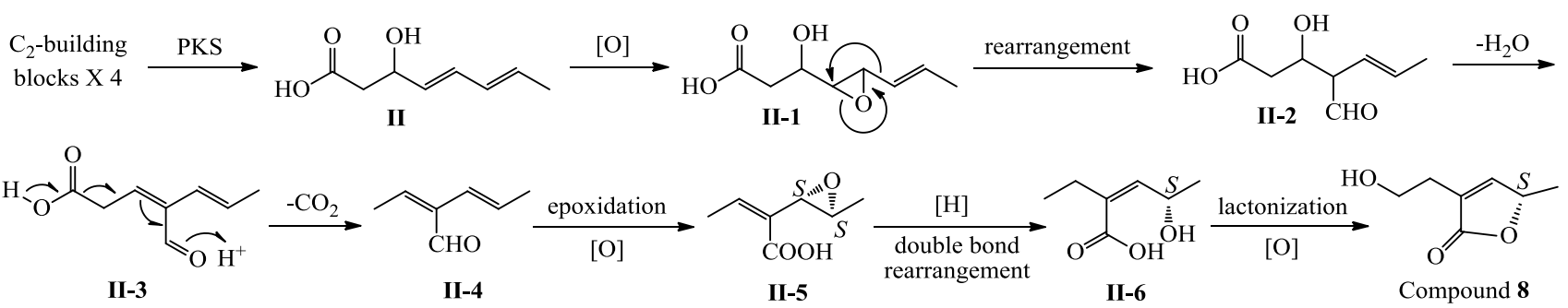

Compound $\mathbf{1 4}$ is also a pentaketide derivative that seems likely to be derived from the intermediate I shown for 1-7 and 9-13 in Scheme 1. A plausible biosynthetic pathway for $\mathbf{1 4}$ is proposed in Scheme 3. Similar to the biosynthesis of 1-7/9-13 (Scheme 1), epoxidation of the double bond adjacent to the methyl group in I, followed by rearrangement, dehydration and decarboxylation reactions, would give a key intermediate III-2, which underwent further modification would produce 14 (Scheme 3).

Scheme 3. Plausible biosynthetic pathway of 14.

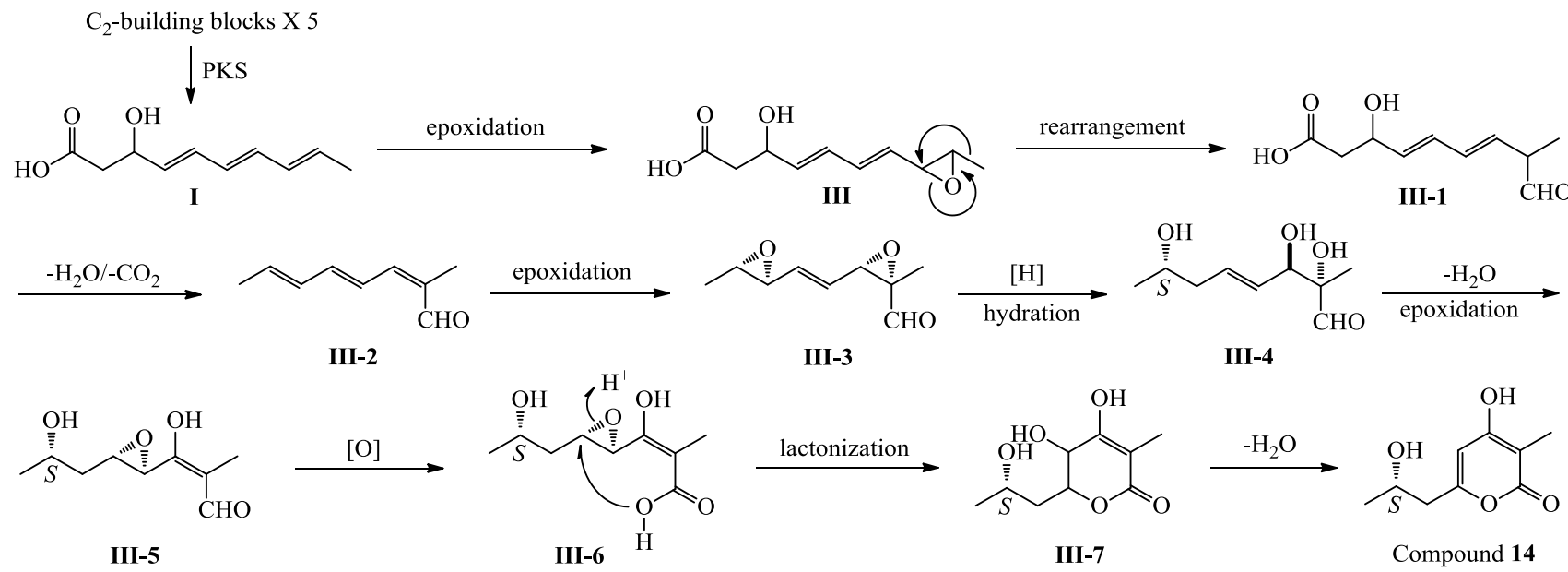

In present MTT assay, $\mathbf{9}$ and $\mathbf{1 1}$ showed stronger inhibitory effect than the others on human cancer K562 and/or HL-60 cell lines. Compound 9 inhibited the HL-60 cells with the IR\% value of $67.2 \%$ at $100 \mu \mathrm{g} / \mathrm{mL}$, while 11 inhibited the K562 and HL-60 cells with the IR\% values of $79.7 \%$ and $72.5 \%$ at $100 \mu \mathrm{g} / \mathrm{mL}$, respectively. Both compounds also inhibited to some extents the K562 (9: an IR\% of $27.9 \%$ at $100 \mu \mathrm{g} / \mathrm{mL}$ ) and the BGC-823 (11: an IR\% of $21.8 \%$ at $100 \mu \mathrm{g} / \mathrm{mL})$ cells. These data suggested that the new compounds $\mathbf{9}$ and $\mathbf{1 1}$ showed somewhat selective inhibitory effect on the HL-60 cells and the K562 and HL-60 cells, respectively, although the inhibitory effect of both compounds by the $\mathrm{IC}_{50}$ of $9(52.1 \mu \mathrm{g} / \mathrm{mL}$ or $241.2 \mu \mathrm{M}$ on HL-60) and $11(44.3 \mu \mathrm{g} / \mathrm{mL}$ or $260.6 \mu \mathrm{M}$ on $\mathrm{K} 562$ and $32.8 \mu \mathrm{g} / \mathrm{mL}$ or $192.9 \mu \mathrm{M}$ on HL-60) is not so exciting. On the other hand, except three other new compounds 3-4 weakly inhibited the K562 and HL-60 cells with the IR\% values larger than 20\% at $100 \mu \mathrm{g} / \mathrm{mL}$, all the others showed very weak effect on some of the tested four cancer cell lines with the IR\% values lower than $20 \%$ at $100 \mu \mathrm{g} / \mathrm{mL}$, as shown in Section 2.3. Aspyrone and asperlactone have been identified for some biological activities, including the remarkable insect growth regulator activity of asperlactone against Tribolium castaneum and Nezara viridula [48], the nematicidal activity of aspyrone on Pratylenchus penetrans [49], and the antifungal and antibacterial activities of both 
compounds on several fungal and bacterial strains [50]. Antibacterial activities were also reported for several chlorine containing derivatives from aspyrone and asperlactone by opening of the epoxy ring therein [22,51]. Although aspinonene and mono $(S)$ - and $(R)$-MTRA esters of dihydroaspyrone $(\mathbf{1 0})$ at C-9 have been reported to show a low cytotoxicity on mouse lymphocytic leukemia cells [19], there are few of reports recorded the antitumor activities for the compounds structurally closely related to 1-14. The present bioassay results, as well as the report in the literature [19], seem to suggest that the branched $\mathrm{C}_{9}$ polyketides structurally related to 1-14 were likely worthy for further extended studies to obtain antitumor agents with more strong activity and higher selectivity.

\section{Experimental Section}

\subsection{General Experimental}

Melting point was measured on a Beijing Tiandiyu X-4 exact micro melting point apparatus (Tiandiyu science and technology Co., Ltd., Beijing, China) and the temperatures were not corrected. Optical rotations were measured on an Optical Activity Limited polAAr 3005 spectropolarimeter (Optical Activity Limited, Ramsey, UK). ESIMS was recorded on an Applied Biosystems API 3000 LC-MS spectrometer (AB SCIEX, Framingham, MA, USA) and HRESIMS was measured on an Agilent 6520 Q-TOF LC-MS spectrometer (Agilent Technologies, Santa Clara, CA, USA). IR spectra were taken on a Bruker Tensor-27 infrared spectrophotometer (Bruker, Karlsruhe, Germany). CD and ICD data were recorded on a Biologic Science MOS450 CD spectropolarimeter (Bio-Logic, Pont-de-Claix, France). 1D and 2D NMR spectra were obtained on a JEOL JNM-GX 400 (400 MHz ${ }^{1} \mathrm{H}$ and $100 \mathrm{MHz}{ }^{13} \mathrm{C}$ NMR) NMR spectrometer (JEOL Ltd., Tokyo, Japan). The chemical shifts of ${ }^{1} \mathrm{H}$ and ${ }^{13} \mathrm{C}$ NMR signals were recorded in $\delta$ values using the solvent signals $\left(\mathrm{CDCl}_{3}: \delta_{\mathrm{H}} 7.26 / \delta_{\mathrm{C}} 77.1\right.$; $\left.\mathrm{CD}_{3} \mathrm{OD}: \delta_{\mathrm{H}} 3.31 / \delta_{\mathrm{C}} 49.0\right)$ as references, respectively.

Precoated silica gel $\mathrm{GF}_{254}$ plates $(10 \mathrm{~cm} \times 20 \mathrm{~cm}, 0.25 \mathrm{~mm}$ thickness, Yantai Chemical Industrial Institute, Yantai, China) were used in TLC, and spots were detected under UV lights (254 and $365 \mathrm{~nm}$ ) or by using the $10 \%$ sulfuric acid reagent or Vaughan's reagent [39,52]. Silica gel H (100-200 mesh, Yantai Chemical Industrial Institute, Yantai, China), YMC ${ }^{*} \mathrm{GEL}^{\circledR}$ ODS-A-HG $(12 \mathrm{~nm}$ S-50 $\mu \mathrm{m}$, YMC Co., Ltd., Kyoto, Japan), and Sephadex ${ }^{\mathrm{TM}}$ LH-20 (GE Healthcare, Uppsala, Sweden) were used for column chromatography. HPLC was performed on a Waters HPLC systems equipped with Waters 600 controller, Waters 600 pump, Waters 2414 refractive index detector, Waters 2996 (for analytical HPLC) or 2998 (for preparative HPLC) photodiode array detector, and Waters Empower ${ }^{\mathrm{TM}}$ software. The Capcell Pak C18 columns (UG120 Å, $4.6 \times 250 \mathrm{~mm}$ and $20 \times 250 \mathrm{~mm}$; Shiseido Co., Ltd., Tokyo, Japan) were used in analytical and preparative HPLC, respectively.

Human chronic myelogenous leukemia K562 cell line was provided by Prof. Dr. Lili Wang (Beijing Institute of Pharmacology and Toxicology, Beijing, China). Human acute promyelocytic leukemia HL-60, human cervical cancer HeLa, and Human gastric adenocarcinoma BGC-823 cell lines were provided by Prof. Dr. Wenxia Zhou (Beijing Institute of Pharmacology and Toxicology). Fetal bovine serum was purchased from Tianjin Hao Yang Biological manufacture Co., Ltd. (Tianjin, China). The RPMI-1640 medium was purchased from Gibco (lot No. 1403238) and MTT from Amresco (lot No. 0793). Streptomycin (lot No. 071104) and penicillin (lot No. X1103302) were purchased from 
North China Pharmaceutical Group Corporation, China. Docetaxol (DOC, lot No.20110326) was purchased from Beijing Chimivo Technology Co., Ltd. (Beijing, China).

\subsection{Producing Strain, Fermentation and Extraction}

The producing fungal strain 16-02-1 was isolated from a deep-sea sediment, DY19-4-TVG11, which was collected at a Lau Basin hydrothermal vent (depth $2255 \mathrm{~m}$, temperature $114{ }^{\circ} \mathrm{C}$ ) in the southwest Pacific (south latitude $20.9280^{\circ}$, west longitude $176.2401^{\circ}$ ) during round-the-world ocean research of Dayangyihao in May 2007. This strain was identified as a species of the genus Aspergillus by sequence analysis of the ITS region of the rDNA and by morphological characteristics.

For fermentation of the 16-02-1 strain, a spore suspension was prepared using fresh spores by the method that we have previously reported $[39,52]$ at first. Then, the fermentation was carried out in sixteen of $500 \mathrm{~mL}$ Erlenmeyer flasks, each containing $80 \mathrm{~g}$ of rice. Distilled water $(120 \mathrm{~mL})$ was added to each flask, and the contents were soaked overnight before autoclaving at $121{ }^{\circ} \mathrm{C}$ for $30 \mathrm{~min}$. After cooling to room temperature, each flask was inoculated with $200 \mu \mathrm{L}$ of the $16-02-1$ spore suspension and incubated at $28{ }^{\circ} \mathrm{C}$ for 36 days. The fermented material was extracted repeatedly with EtOAc $(3 \times 6 \mathrm{~L})$, and the organic solvent was evaporated under reduced pressure to obtain an EtOAc extract (21.9 g). The EtOAc extract inhibited K562 cells with an IR\% of $76.8 \%$ at $100 \mu \mathrm{g} / \mathrm{mL}$.

\subsection{Isolation of $\mathbf{1}-\mathbf{1 4}$}

The EtOAc extract $(21.9 \mathrm{~g}$ ) was subjected to silica gel column (silica gel $140 \mathrm{~g}$, bed $6.0 \times 30 \mathrm{~cm}$ ) chromatography by stepwise elution with b.p. $60-90{ }^{\circ} \mathrm{C}$ petroleum ether $(P)$-dichloromethane (D)-MeOH (M) to obtain three fractions: Fr-4 (5.7 g, eluted by DM 30:1, IR\% 55.9\% at $100 \mu \mathrm{g} / \mathrm{mL}$ on K562 cells: the following IR\% value in each bracket all indicate the IR\% of the fraction at $100 \mu \mathrm{g} / \mathrm{mL}$ on K562 cells), Fr-5 (5.4 g, eluted by DM 20:1, IR\% 80.2\%) and Fr-6 (2.5 g, eluted by DM 9:1, IR\% 78.6\%).

Fr-4 (5.7 g) was separated by Sephadex LH-20 column (bed $1.5 \times 135 \mathrm{~cm}$ ) chromatography using DM 1:1 as eluting solvent to obtain three fractions Fr-4-1-Fr-4-3. Fr-4-1 (2.2 g, IR\% 75.4\%) was subjected to ODS column (bed $1.2 \times 10 \mathrm{~cm})$ and eluted with $\mathrm{MeOH}-\mathrm{H}_{2} \mathrm{O}(20: 80 \rightarrow 90: 10)$ to afford three fractions Fr-4-1-1-Fr-4-1-3. Fr-4-1-2 was then subjected to preparative HPLC (Capcell Pak $\mathrm{C} 18,20 \mathrm{~mm} \times 250 \mathrm{~mm}$, room temperature; $20 \% \mathrm{MeOH}$ at initial time $0 \mathrm{~min} \rightarrow 100 \% \mathrm{MeOH}$ at $20 \mathrm{~min} \rightarrow 100 \% \mathrm{MeOH}$ at $50 \mathrm{~min}$; flow rate, $10 \mathrm{~mL} / \mathrm{min}$; detecting wave length $210 \mathrm{~nm}$ ) to obtain $2\left(6.5 \mathrm{mg}, t_{\mathrm{R}}=14.1 \mathrm{~min}\right)$ and $8\left(13 \mathrm{mg}, t_{\mathrm{R}}=9.9 \mathrm{~min}\right)$. Fr-4-2 (2.7 g, IR\% 42.3\%) was subjected to ODS column (bed $1.2 \times 10 \mathrm{~cm}$ ) chromatography and stepwise elution by $\mathrm{MeOH}-\mathrm{H}_{2} \mathrm{O}(20: 80 \rightarrow 90: 10)$ afforded three fractions Fr-4-2-1-Fr-4-2-3. A preparative HPLC separation (Capcell Pak C18 column, $20 \mathrm{~mm} \times 250 \mathrm{~mm}$, at the room temperature; $20 \% \mathrm{MeOH}$ at initial time $0 \mathrm{~min} \rightarrow 100 \% \mathrm{MeOH}$ at $30 \mathrm{~min}$; flow rate, $10 \mathrm{~mL} / \mathrm{min}$; detecting wave length $210 \mathrm{~nm})$ of Fr-4-2-3 (1.8 g, IR\% 40.1\%) gave 1 (9 mg, $\left.t_{\mathrm{R}}=9.2 \mathrm{~min}\right)$ and five fractions Fr-4-2-3-1-Fr-4-2-3-5. Separation of Fr-4-2-3-3 (28 mg) by preparative $\mathrm{HPLC}$ at the same condition except for the mobile phase $\mathrm{MeOH}-\mathrm{H}_{2} \mathrm{O}$ 95:5 gave 5 (6.5 $\mathrm{mg}$, $\left.t_{\mathrm{R}}=35.5 \mathrm{~min}\right)$, and separation of Fr-4-2-3-4 $(28 \mathrm{mg})$ by preparative HPLC at the same condition using the mobile phase $\mathrm{MeOH}-\mathrm{H}_{2} \mathrm{O} 94: 6$ afforded $9\left(7 \mathrm{mg}, t_{\mathrm{R}}=33.3 \mathrm{~min}\right)$. 
Fr-5 (5.4 g) was subjected Sephadex LH-20 column (bed $1.5 \times 135 \mathrm{~cm}$ ) chromatography eluted with DM 1:1 to separate into three fractions Fr-5-1-Fr-5-3. Fr-5-2 (1.2 g, IR\% 40.1\%) was subjected to preparative HPLC (Capcell Pak C18 column, $20 \mathrm{~mm} \times 250 \mathrm{~mm}$, room temperature; $20 \% \mathrm{MeOH}$ at initial time $0 \mathrm{~min} \rightarrow 100 \% \mathrm{MeOH}$ at $50 \mathrm{~min}$; flow rate, $10 \mathrm{~mL} / \mathrm{min}$; detecting wave length $210 \mathrm{~nm}$ ) to obtain $11\left(12 \mathrm{mg}, t_{\mathrm{R}}=13.2 \mathrm{~min}\right)$ and $\mathbf{1 0}\left(141 \mathrm{mg}, t_{\mathrm{R}}=11.8 \mathrm{~min}\right)$.

Fr-6 (2.5 g) was subjected to ODS column (bed $1.2 \times 10 \mathrm{~cm}$ ) chromatography eluted with $\mathrm{MeOH}-\mathrm{H}_{2} \mathrm{O}$ $(20: 80 \rightarrow 90: 10)$ to give three fractions Fr-6-1-Fr-6-3. Fr-6-2 (1.7 g, IR\% 62.5\%) was separated by preparative HPLC (Capcell Pak C18 column, $20 \mathrm{~mm} \times 250 \mathrm{~mm}$, room temperature; $10 \% \mathrm{MeOH}$ at initial time $0 \mathrm{~min} \rightarrow 100 \% \mathrm{MeOH}$ at $50 \mathrm{~min}$; flow rate, $10 \mathrm{~mL} / \mathrm{min}$; detecting wave length $210 \mathrm{~nm}$ ) to obtain 6/7 $\left(19 \mathrm{mg}, t_{\mathrm{R}}=13.6 \mathrm{~min}\right), \mathbf{1 3}\left(19 \mathrm{mg}, t_{\mathrm{R}}=15.8 \mathrm{~min}\right)$ and a fraction $\left(29 \mathrm{mg}, t_{\mathrm{R}}=6 \mathrm{~min}\right)$ containing 3 and 4 . This fraction $(29 \mathrm{mg}$ ) was further separated by preparative HPLC at the same condition except for the mobile phase $\mathrm{MeOH}-\mathrm{H}_{2} \mathrm{O} 90: 10$ to obtain $3\left(9 \mathrm{mg}, t_{\mathrm{R}}=13.6 \mathrm{~min}\right)$ and $4\left(7 \mathrm{mg}, t_{\mathrm{R}}=16.0 \mathrm{~min}\right)$. Fr-6-3 $(872 \mathrm{mg}$, IR\% 30.1\%) was separated by preparative HPLC at the same conditions as described for Fr-6-2 to obtain $12\left(21 \mathrm{mg}, t_{\mathrm{R}}=18.8 \mathrm{~min}\right)$ and $\mathbf{1 4}\left(31 \mathrm{mg}, t_{\mathrm{R}}=23.7 \mathrm{~min}\right)$.

\subsection{Physicochemical and Spectroscopic Data of 1-14}

Aspiketolactonol (1): Colorless oil $(\mathrm{MeOH}),[\alpha]_{\mathrm{D}}^{25}+10.5$ (c 1.2, MeOH). Positive ion ESIMS $m / z$ : $185[\mathrm{M}+\mathrm{H}]^{+}, 207[\mathrm{M}+\mathrm{Na}]^{+}$; Negative ion ESIMS $m / z: 183[\mathrm{M}-\mathrm{H}]^{-}$. Positive ion HRESIMS $m / z$ : measured 185.0811 $[\mathrm{M}+\mathrm{H}]^{+}$, calculated for $\mathrm{C}_{9} \mathrm{H}_{13} \mathrm{O}_{4}[\mathrm{M}+\mathrm{H}]^{+}$185.0814; measured 207.0631 $[\mathrm{M}+\mathrm{Na}]^{+}$, calculated for $\mathrm{C}_{9} \mathrm{H}_{12} \mathrm{O}_{4} \mathrm{Na}[\mathrm{M}+\mathrm{Na}]^{+}$207.0633. UV $\lambda_{\max } \mathrm{nm}$ in $\mathrm{MeOH}: 213 \mathrm{~nm}$. IR $v_{\max } \mathrm{cm}^{-1}$ (Diamond ATR crystal): 3417, 3090, 2980, 2938, 2906, 1752, 1722, 1656, 1422, 1360, 1323, 1207 , 1166, 1138, 1081, 1024, 982, 935, 896. CD $\Delta \varepsilon(\mathrm{nm}): 0$ (192.5), -0.44 (198.0), -0.30 (207.5), -0.32 (209.5), -0.21 (215.0), -0.23 (216.5), 0 (226.0), +0.34 (233.0), +0.07 (244.5), 0 (282). ${ }^{1} \mathrm{H}$ and ${ }^{13} \mathrm{C}$ NMR data: Tables 1 and 2 .

Aspilactonol A (2): Colorless oil (MeOH), $[\alpha]_{\mathrm{D}}^{25}+24.6$ (c 0.23, MeOH). Positive ion ESIMS $m / z$ : $171[\mathrm{M}+\mathrm{H}]^{+}, 193[\mathrm{M}+\mathrm{Na}]^{+}$. Positive ion HRESIMS $m / z$ : measured $171.1015[\mathrm{M}+\mathrm{H}]^{+}$, calculated for $\mathrm{C}_{9} \mathrm{H}_{15} \mathrm{O}_{3}[\mathrm{M}+\mathrm{H}]^{+}$171.1021; measured $193.0836[\mathrm{M}+\mathrm{Na}]^{+}$, calculated for $\mathrm{C}_{9} \mathrm{H}_{14} \mathrm{O}_{3} \mathrm{Na}[\mathrm{M}+\mathrm{Na}]^{+}$ 193.0841; measured 209.0573 [M+K] $]^{+}$, calculated for $\mathrm{C}_{9} \mathrm{H}_{14} \mathrm{O}_{3} \mathrm{~K}[\mathrm{M}+\mathrm{Na}]^{+}$209.0580. UV $\lambda_{\max } \mathrm{nm}$ in MeOH: $210 \mathrm{~nm}$. IR $v_{\max } \mathrm{cm}^{-1}$ (Diamond ATR crystal): 3436, 3080, 2971, 2932, 1746, 1653, 1449, 1406, 1374, 1320, 1201, 1030, 960, 870, 786. CD $\Delta \varepsilon$ (nm): 0 (191.0), -0.49 (198.0), -0.30 (206.0), -0.33 (208.5), -0.25 (214.0), -0.26 (215.5), 0 (219.5), +0.70 (225.0), 0 (229.5), -0.60 (237.5), -0.59 (240.5), 0 (279.5). ${ }^{1} \mathrm{H}$ and ${ }^{13} \mathrm{C}$ NMR data: Tables 1 and 2.

Aspilactonol B (3): Colorless oil $(\mathrm{MeOH}),[\alpha]_{\mathrm{D}}^{25}+34.5(c$ 0.41, MeOH). Positive ion ESIMS $m / z$ : $203[\mathrm{M}+\mathrm{H}]^{+}, 225[\mathrm{M}+\mathrm{Na}]^{+}$; Negative ion ESIMS $m / z: 201[\mathrm{M}-\mathrm{H}]^{-}$. Positive ion HRESIMS $m / z$ : measured 203.0919 $[\mathrm{M}+\mathrm{H}]^{+}$, calculated for $\mathrm{C}_{9} \mathrm{H}_{15} \mathrm{O}_{5}[\mathrm{M}+\mathrm{H}]^{+}$203.0919; measured 225.0736 [M+ Na $]^{+}$, calculated for $\mathrm{C}_{9} \mathrm{H}_{14} \mathrm{O}_{5} \mathrm{Na}[\mathrm{M}+\mathrm{Na}]^{+}$225.0739. UV $\lambda_{\max } \mathrm{nm}$ in $\mathrm{MeOH}: 214 \mathrm{~nm}$. IR $v_{\max } \mathrm{cm}^{-1}$ (Diamond ATR crystal): 3388, 3095, 2978, 2936, 2900, 2831, 1742, 1653, 1451, 1406, 1378, 1314, 1200, 1136, 1069, 996, 934, 894, 870, 830, 803, 770, 721, 698. CD $\Delta \varepsilon$ (nm): 0 (192.0), -0.78 (197.0), 0 (206.5), +2.02 (226.5), 0 (282.5). ${ }^{1} \mathrm{H}$ and ${ }^{13} \mathrm{C}$ NMR data: Tables 1 and 2. 
Aspilactonol C (4): Colorless oil $(\mathrm{MeOH}),[\alpha]_{\mathrm{D}}^{25}+27.2(c \quad 0.32, \mathrm{MeOH})$. Positive ion ESIMS $m / z$ : $203[\mathrm{M}+\mathrm{H}]^{+}, 225[\mathrm{M}+\mathrm{Na}]^{+}$; Negative ion ESIMS $m / z: 201[\mathrm{M}-\mathrm{H}]^{-}$. Positive ion HRESIMS $m / z$ : measured 203.0910 $[\mathrm{M}+\mathrm{H}]^{+}$, calculated for $\mathrm{C}_{9} \mathrm{H}_{15} \mathrm{O}_{5}[\mathrm{M}+\mathrm{H}]^{+}$203.0919; measured 225.0732 [M + Na] $]^{+}$, calculated for $\mathrm{C}_{9} \mathrm{H}_{14} \mathrm{O}_{5} \mathrm{Na}[\mathrm{M}+\mathrm{Na}]^{+}$225.0739; measured $241.0476[\mathrm{M}+\mathrm{K}]^{+}$, calculated for $\mathrm{C}_{9} \mathrm{H}_{14} \mathrm{O}_{5} \mathrm{~K}[\mathrm{M}+\mathrm{K}]^{+}$241.0478. UV $\lambda_{\max } \mathrm{nm}$ in MeOH: $214 \mathrm{~nm}$. IR $v_{\max } \mathrm{cm}^{-1}$ (Diamond ATR crystal): 3379, 3092, 2979, 2935, 1737, 1651, 1450, 1402, 1377, 1300, 1200, 1133, 1063, 994, 933, 894, 868, 826, 763, 693. CD $\Delta \varepsilon(\mathrm{nm}): 0$ (192.0), -0.43 (196.5), -0.39 (197.0), -0.41 (197.5), 0 (201.5), +0.37 (210.5), +1.64 (225.5), +1.65 (226.0), 0 (242.0), -0.19 (251.5), 0 (275.0). ${ }^{1} \mathrm{H}$ and ${ }^{13} \mathrm{C}$ NMR data: Tables 1 and 2.

Aspilactonol D (5): Colorless oil $(\mathrm{MeOH}),[\alpha]_{\mathrm{D}}^{25}-1.7(c$ 0.38, MeOH). Positive ion ESIMS $m / z$ : $217[\mathrm{M}+\mathrm{H}]^{+}, 239[\mathrm{M}+\mathrm{Na}]^{+}$. Positive ion HRESIMS $m / z$ : measured $217.1071[\mathrm{M}+\mathrm{H}]^{+}$, calculated for $\mathrm{C}_{10} \mathrm{H}_{17} \mathrm{O}_{5}[\mathrm{M}+\mathrm{H}]^{+}$217.1076; measured 239.0890 [M $\left.+\mathrm{Na}\right]^{+}$, calculated for $\mathrm{C}_{10} \mathrm{H}_{16} \mathrm{O}_{5} \mathrm{Na}[\mathrm{M}+\mathrm{Na}]^{+}$ 239.0895; measured 255.0635 [M $+\mathrm{K}]^{+}$, calculated for $\mathrm{C}_{10} \mathrm{H}_{16} \mathrm{O}_{5} \mathrm{~K}[\mathrm{M}+\mathrm{K}]^{+}$255.0635. UV $\lambda_{\max } \mathrm{nm}$ in MeOH: $213 \mathrm{~nm}$. IR $v_{\max } \mathrm{cm}^{-1}$ (Diamond ATR crystal): 3401, 3088, 2978, 2937, 2902, 2832, 1750, $1655,1451,1378,1298,1256,1200,1136,1108,1066,1022,977,950,936,894,853,833,803,780$, 717. CD $\Delta \varepsilon(\mathrm{nm}): 0$ (193.5), -0.29 (196.5), 0 (203.5), +1.41 (231.5), 0 (271.0). ${ }^{1} \mathrm{H}$ and ${ }^{13} \mathrm{C}$ NMR data: Tables 1 and 2.

Aspilactonols E/F (6/7): Colorless oil $(\mathrm{MeOH}),[\alpha]_{\mathrm{D}}^{25}+78.1$ ( $c$ 1.00, MeOH). Positive ion ESIMS $m / z$ : $187[\mathrm{M}+\mathrm{H}]^{+}, 209[\mathrm{M}+\mathrm{Na}]^{+}$; Negative ion ESIMS $m / z: 185[\mathrm{M}-\mathrm{H}]^{-}$. Positive ion HRESIMS $m / z$ : measured 187.0967 $[\mathrm{M}+\mathrm{H}]^{+}$, calculated for $\mathrm{C}_{9} \mathrm{H}_{15} \mathrm{O}_{5}[\mathrm{M}+\mathrm{H}]^{+}$187.0970; measured 209.0789 $[\mathrm{M}+\mathrm{Na}]^{+}$, calculated for $\mathrm{C}_{9} \mathrm{H}_{14} \mathrm{O}_{5} \mathrm{Na}[\mathrm{M}+\mathrm{Na}]^{+}$209.0790. UV $\lambda_{\max } \mathrm{nm}$ in $\mathrm{MeOH}: 213 \mathrm{~nm}$. IR $v_{\max } \mathrm{cm}^{-1}$ (Diamond ATR crystal): 3396, 3093, 2975, 2934, 1748, 1651, 1456, 1417, 1377, 1205, 1127, 1070, 990, 942, 882, 841, 677. CD $\Delta \varepsilon$ (nm): 0 (185.0), -0.55 (196.5), -0.09 (201.5), -0.05 (202.5), -0.07 (214.0), 0 (216.5), +2.78 (228.5), 0 (280.5). ${ }^{1} \mathrm{H}$ and ${ }^{13} \mathrm{C}$ NMR data: Tables 1 and 2.

Aspyronol (9): Colorless oil $(\mathrm{MeOH}),[\alpha]_{\mathrm{D}}^{25}-41.6$ (c $\left.0.22, \mathrm{MeOH}\right)$. Positive ion ESIMS $m / z$ : $217[\mathrm{M}+\mathrm{H}]^{+}, 239[\mathrm{M}+\mathrm{Na}]^{+}$. Positive ion HRESIMS $m / z$ : measured $217.1073[\mathrm{M}+\mathrm{H}]^{+}$, calculated for $\mathrm{C}_{10} \mathrm{H}_{17} \mathrm{O}_{5}[\mathrm{M}+\mathrm{H}]^{+}$217.1076; measured 239.0896 [M $\left.+\mathrm{Na}\right]^{+}$, calculated for $\mathrm{C}_{10} \mathrm{H}_{16} \mathrm{O}_{5} \mathrm{Na}[\mathrm{M}+\mathrm{Na}]^{+}$ 239.0895; measured 255.0634 [M $+\mathrm{K}]^{+}$, calculated for $\mathrm{C}_{10} \mathrm{H}_{16} \mathrm{O}_{5} \mathrm{~K}[\mathrm{M}+\mathrm{K}]^{+}$255.0635. UV $\lambda_{\max } \mathrm{nm}$ in MeOH: $208 \mathrm{~nm}$. IR $v_{\max } \mathrm{cm}^{-1}$ (Diamond ATR crystal): 3398, 2982, 2938, 2905, 2835, 1714, 1649, 1451, 1384, 1309, 1216, 1044, 1018, 783, 721, 669. CD $\Delta \varepsilon$ (nm): 0 (192.0), -0.53 (196.5), -0.72 (209.5), -2.81 (223.5), 0 (242.0), -1.22 (263.0), 0 (301.0). ${ }^{1} \mathrm{H}$ and ${ }^{13} \mathrm{C}$ NMR data: Table 3.

Epiaspinonediol (11): Colorless oil $(\mathrm{MeOH}),[\alpha]_{\mathrm{D}}^{25}-5.4(c$ 0.14, MeOH). Positive ion ESIMS $m / z$ : $193[\mathrm{M}+\mathrm{Na}]^{+}, 209[\mathrm{M}+\mathrm{K}]^{+}$. Positive ion HRESIMS $m / z$ : measured $171.1003[\mathrm{M}+\mathrm{H}]^{+}$, calculated for $\mathrm{C}_{9} \mathrm{H}_{15} \mathrm{O}_{3}[\mathrm{M}+\mathrm{H}]^{+}$171.1021; measured $193.0842[\mathrm{M}+\mathrm{Na}]^{+}$, calculated for $\mathrm{C}_{9} \mathrm{H}_{14} \mathrm{O}_{3} \mathrm{Na}[\mathrm{M}+\mathrm{Na}]^{+}$ 193.0841. ${ }^{1} \mathrm{H}$ NMR (400 MHz, CD $\left.{ }_{3} \mathrm{OD}\right) \delta: 7.20(1 \mathrm{H}, \mathrm{d}, J=16.2 \mathrm{~Hz}, \mathrm{H}-4), 6.41(1 \mathrm{H}, \mathrm{d}, J=16.2 \mathrm{~Hz}$, H-3), 6.05 (1H, d, $J=8.4$ Hz, H-6), 4.77 (1H, dq, $J=8.4,6.4$ Hz, H-7), 4.33 (2H, s, H-9), 2.31 (3H, s, $\mathrm{H}-1), 1.29(3 \mathrm{H}, \mathrm{d}, J=6.4 \mathrm{~Hz}, \mathrm{H}-8) .{ }^{13} \mathrm{C}$ NMR (100 MHz, CD $\left.\mathrm{OD}\right) \delta: 201.6(\mathrm{C}-2), 148.3(\mathrm{C}-6), 147.5$ (C-4), 137.0 (C-5), 128.4 (C-3), 64.8 (C-7), 56.9 (C-9), 27.3 (C), 23.6 (C-8).

The data for five known compounds, 8, 10 and 12-14, and the spectra of the new compounds, 1-7, $\mathbf{9}$ and 11, are all given in the Supplementary Information. 


\subsection{Preparation of (S)- and (R)-MTPA Esters of 1, 5 and 9}

Each of duplicate $2(0.3 \mathrm{mg}, 1.8 \mu \mathrm{mol}), \mathbf{5}(0.5 \mathrm{mg}, 2.3 \mu \mathrm{mol})$ and $9(0.3 \mathrm{mg}, 1.4 \mu \mathrm{mol})$ in $0.2 \mathrm{~mL}$ unhydrous pyridine- $d_{6}$ in NMR tubes was reacted with $(S)$ - and $(R)$-MPTA-Cl $(1.65 \mu \mathrm{L}, 8.8 \mu$ mol for 2; $4.40 \mu \mathrm{L}, 23.1 \mu \mathrm{mol}$ for 5 ; $2.63 \mu \mathrm{L}, 13.9 \mu \mathrm{mol}$ for 9), respectively. The reaction was performed at room temperature for $72 \mathrm{~h}$. Then, the ${ }^{1} \mathrm{H}$ NMR data of the $(S)$ - and $(R)$-MTPA esters were obtained without purification.

Compound 2a (pyridine- $\left.d_{5}, 400 \mathrm{MHz}\right) \delta: 7.10(1 \mathrm{H}$, br s, H-4), $5.30(1 \mathrm{H}, \mathrm{m}, \mathrm{H}-9), 4.99(1 \mathrm{H}, \mathrm{m}$, H-5), 2.41 (2H, m, H-7), 1.87 (2H, m, H-8), 1.24 (3H, d, J=6.5 Hz, H-6), 1.23 (3H, d, J=6.2 Hz, H-10).

Compound $2 \mathbf{b}$ (pyridine- $\left.d_{5}, 400 \mathrm{MHz}\right) \delta$ : $7.02(1 \mathrm{H}$, br s, H-4), $5.31(1 \mathrm{H}, \mathrm{m}, \mathrm{H}-9), 4.97(1 \mathrm{H}, \mathrm{m}$, H-5), 2.28 (2H, m, H-7), 1.84 (2H, m, H-8), 1.31 (3H, d, J=6.3 Hz, H-10), 1.22 (3H, d, J=6.9 Hz, H-6).

Compound 5a (pyridine- $\left.d_{5}, 400 \mathrm{MHz}\right) \delta: 5.87(1 \mathrm{H}, \mathrm{m}, \mathrm{H}-9), 5.25(1 \mathrm{H}, \mathrm{m}, \mathrm{H}-5), 4.59$ (1H, m, H-6), $4.42(1 \mathrm{H}$, br d, $J=4.0 \mathrm{~Hz}, \mathrm{H}-8), 3.24\left(3 \mathrm{H}, \mathrm{s}, \mathrm{OC}_{3}\right), 1.79(3 \mathrm{H}, \mathrm{d}, J=7.4 \mathrm{~Hz}, \mathrm{H}-7), 1.37$ (3H, d, $J=6.5 \mathrm{~Hz}, \mathrm{H}-10)$.

Compound $5 \mathbf{b}$ (pyridine- $\left.d_{5}, 400 \mathrm{MHz}\right) \delta: 5.83$ (1H, m, H-9), $5.33(1 \mathrm{H}, \mathrm{m}, \mathrm{H}-5), 4.60$ (1H, m, 6-H), $4.54(1 \mathrm{H}$, br d, $J=3.9 \mathrm{~Hz}, \mathrm{H}-8), 3.34\left(3 \mathrm{H}, \mathrm{s}, \mathrm{OCH}_{3}\right), 1.80(3 \mathrm{H}, \mathrm{d}, J=7.4 \mathrm{~Hz}, \mathrm{H}-7), 1.31(3 \mathrm{H}, \mathrm{d}$, $J=6.5 \mathrm{~Hz}, \mathrm{H}-10)$.

Compound 9a (pyridine- $\left.d_{5}, 400 \mathrm{MHz}\right) \delta: 7.18(1 \mathrm{H}, \mathrm{m}, \mathrm{H}-4), 5.93(1 \mathrm{H}, \mathrm{m}, \mathrm{H}-5), 5,7860$ (1H, m, H-9), $4.58(1 \mathrm{H}, \mathrm{m}, \mathrm{H}-8), 4.57$ (1H, m, H-6), $3.19\left(3 \mathrm{H}, \mathrm{s}, \mathrm{OC}_{3}\right), 1.39$ (3H, d, J=6.3 Hz, H-7), 1.28 (3H, d, $J=6.4 \mathrm{~Hz}, \mathrm{H}-10)$.

Compound 9b (pyridine- $\left.d_{5}, 400 \mathrm{MHz}\right) \delta: 7.19$ (1H, m, H-4), 6.03 (1H, m, H-5), 5.7827 (1H, m, H-9), $4.88(1 \mathrm{H}, \mathrm{m}, \mathrm{H}-6), 4.72(1 \mathrm{H}, \mathrm{m}, \mathrm{H}-8), 3.29\left(3 \mathrm{H}, \mathrm{s}, \mathrm{OC}_{3}\right), 1.45(3 \mathrm{H}, \mathrm{d}, J=6.5 \mathrm{~Hz}, \mathrm{H}-7), 1.22(3 \mathrm{H}, \mathrm{d}$, $J=6.6 \mathrm{~Hz}, \mathrm{H}-10)$.

\subsection{Measurement of ICD Spectra of 3 and 4 Using $\mathrm{Mo}_{2}(\mathrm{OAc})_{4}$}

ICD was measured according to our previous procedure [39] using spectroscopy grade unhydrous DMSO. A mixture of the ligand (3 or 4) and $\mathrm{Mo}_{2}(\mathrm{OAc})_{4}$ in DMSO in an approximate 1:2 molar ratio was subjected to the ICD measurement. The first CD spectrum was recorded immediately after mixing, and its time evolution was monitored until stationary ICD was reached about 10 min after mixing. After the inherent CD data of the compound were subtracted, the ICD spectrum was normalized to the molar concentration of $\mathbf{3}$ or $\mathbf{4}$ and is presented as the $\Delta \varepsilon^{\prime}$ values. The observed signs of the bands II and IV in the ICD were correlated to the absolute configuration of the 1,2-diol moiety.

\subsection{MTT Assay}

All samples and DOC were dissolved in $\mathrm{MeOH}$ to prepare the $\mathrm{MeOH}$ solution at $10.0 \mathrm{mg} / \mathrm{mL}$, and serial dilutions were made for compounds 9 and 11. These solutions were subjected to MTT assay. DOC was used as positive control and $\mathrm{MeOH}$ was used as blank control. The assay was run in triplicate on human cancer K562, HL-60, HeLa and BGC-823 cell lines by the method that we have previously reported [52]. The OD was read at $570 \mathrm{~nm}$, and the IR\% value was calculated using the OD 
mean values by the formula, $\mathrm{IR} \%=\left(\mathrm{OD}_{\text {control }}-\mathrm{OD}_{\text {sample }}\right) / \mathrm{OD}_{\text {control }} \times 100 \%$. The $\mathrm{IC}_{50}$ for 9 and 11 was obtained from their IR\% values at different concentrations.

\section{Conclusions}

Chemical investigation on a deep sea-sourced Aspergillus sp. 16-02-1 has resulted in the elucidation of 14 secondary metabolites, including nine new branched $\mathrm{C}_{9}$ polyketides, named aspiketolactonol (1), aspilactonols A-F (2-7), aspyronol (9) and epiaspinonediol (11), and five known branched polyketides identified as (S)-2-(2'-hydroxyethyl)-4-methyl- $\gamma$-butyrolactone (8), dihydroaspyrone (10), aspinotriol A (12), aspinotriol B (13) and chaetoquadrin F (14). Structures of the new compounds, including their absolute configurations, were determined by extensive spectroscopic methods, especially the 2D NMR, CD, ICD and Mosher's ${ }^{1} \mathrm{H}$ NMR analyses. Compound $\mathbf{8}$ was isolated from the natural sources for the first time, and the possible biosynthetic pathways for 1-14 were also proposed and discussed. Compounds 1-14 inhibited human cancer K562, HL-60, HeLa and BGC-823 cells to varying extents.

\section{Acknowledgments}

This work was supported by the grants from the NHTRDP (2013AA092901, 2007AA09Z411), NSFC (81172976), NSTMP (2012ZX09301-003, 2009ZX09103-019, 2009ZX09301-002), CAS (KSCX2-EW-G-6), and COMRA (DYXM-115-02-2-09), China. Dedicated to Xin-Sheng Yao on the occasion of his 80th birthday.

\section{Author Contributions}

Xiu-Wen Chen, Chang-Wei Li and Wei Hua performed the experiments for biological and chemical investigations on polyketides. Chang-Wei Li especially contributed to the structure elucidation of new compounds and also contributed to the preparation of the manuscript. Tian-Jiao Zhu and Qian-Qun Gu isolated and identified the producing strain Aspergillus sp. 16-02-1. Cheng-Bin Cui conceived and designed the experiments, accomplished the $\mathrm{CD}$ and ICD data analyses and absolute configuration assignments, and wrote the paper.

\section{Conflicts of Interest}

The authors declare no conflict of interest.

\section{References}

1. Blunt, J.W.; Copp, B.R.; Keyzers, R.A.; Munro, M.H.G.; Prinsep, M.R. Marine natural products. Nat. Prod. Rep. 2014, 31, 160-258.

2. Blunt, J.W.; Copp, B.R.; Keyzers, R.A.; Munro, M.H.G.; Prinsep, M.R. Marine natural products. Nat. Prod. Rep. 2013, 30, 237-323.

3. Blunt, J.W.; Copp, B.R.; Keyzers, R.A.; Munro, M.H.G.; Prinsep, M.R. Marine natural products. Nat. Prod. Rep. 2012, 29, 144-222. 
4. Blunt, J.W.; Copp, B.R.; Munro, M.H.G.; Northcote, P.T.; Prinsep, M.R. Marine natural products. Nat. Prod. Rep. 2011, 28, 196-268.

5. Blunt, J.W.; Copp, B.R.; Munro, M.H.G.; Northcote, P.T.; Prinsep, M.R. Marine natural products. Nat. Prod. Rep. 2010, 27, 165-237.

6. Bugni, T.S.; Ireland, C.M. Marine-derived fungi: A chemically and biologically diverse group of microorganisms. Nat. Prod. Rep. 2004, 21, 143-163.

7. Saleem, M.; Ali, M.S.; Hussain, S.; Jabbar, A.; Ashraf, M.; Lee, Y.S. Marine natural products of fungal origin. Nat. Prod. Rep. 2007, 24, 1142-1152.

8. Bhatnagar, I.; Kim, S.-K. Immense essence of excellence: Marine microbial bioactive compounds. Mar. Drugs 2010, 8, 2673-2701.

9. Rateb, M.E.; Ebel, R. Secondary metabolites of fungi from marine habitats. Nat. Prod. Rep. 2011, 28, 290-344.

10. Pejin, B.; Jovanović, K.K.; Mojović, M.; Savić, A.G. New and highly potent antitumor natural products from marine-derived fungi: Covering the period from 2003 to 2012. Curr. Top. Med. Chem. 2013, 13, 2745-2766.

11. Newman, D.J.; Cragg, G.M. Marine-sourced anti-cancer and cancer pain control agents in clinical and late preclinical development. Mar. Drugs 2014, 12, 255-278.

12. Skropeta, D. Deep-sea natural products. Nat. Prod. Rep. 2008, 25, 1131-1166.

13. Li, D.H.; Cai, S.X.; Zhu, T.J.; Wang, F.P.; Xiao, X.; Gu, Q.Q. Three new sorbicillin trimers, trisorbicillinones B, C, and D, from a deep ocean sediment derived fungus, Phialocephala sp. FL30r. Tetrahedron 2010, 66, 5101-5106.

14. Li, Y.; Ye, D.Z.; Shao, Z.Z.; Cui, C.B.; Che, Y.S. A sterol and spiroditerpenoids from a Penicillium sp. isolated from a deep sea sediment sample. Mar. Drugs 2012, 10, 497-508.

15. Wang, F.Z.; Huang, Z.; Shi, X.F.; Chen, Y.C.; Zhang, W.M.; Tian, X.P.; Li, J.; Zhang, S. Cytotoxic indole diketopiperazines from the deep sea-derived fungus Acrostalagmus luteoalbus SCSIO F457. Bioorg. Med. Chem. Lett. 2012, 22, 7265-7267.

16. Chen, Y.; Mao, W.J.; Wang, B.F.; Zhou, L.; Gu, Q.Q.; Chen, Y.L.; Zhao, C.Q.; Li, N.; Wang, C.Y.; Shan, J.M.; et al. Preparation and characterization of an extracellular polysaccharide produced by the deep-sea fungus Penicillium griseofulvum. Bioresour. Technol. 2013, 132, 178-182.

17. Chen, X.W.; Li, C.W.; Hua, W.; Wu, C.J.; Cui, C.B.; Zhu, T.J.; Gu, Q.Q. Metabolites of Aspergillus sp. 16-02-1 isolated from a deep sea sediment and preliminary test of their antitumor and antifungal activities. Chin. J. Mar. Drugs 2013, 32, 1-10.

18. Harmange, J.C.; Figadère, B.; Hocquemiller, R. Enantiospecific preparation of the lactone fragment of murisolin. Tetrahedron Asymmetry 1991, 2, 347-350.

19. Kito, K.; Ookura, R.; Yoshida, S.; Namikoshi, M.; Ooi, T.; Kusumi, T. Pentaketides relating to aspinonene and dihydroaspyrone from a marine-derived fungus, Aspergillus ostianus. J. Nat. Prod. 2007, 70, 2022-2025.

20. Fujimoto, H.; Nozawa, M.; Okuyama, E.; Ishibashi, M. Six new constituents from an ascomycete, Cheatomium quadrangulatum, found in a screening study focused on monoamine oxidase inhibitory activity. Chem. Pharm. Bull. 2003, 51, 247-251. 
21. Garson, M.J.; Staunton, J. New polyketide metabolites from Aspergmus melleus: Structural and stereochemical studies. J. Chem. Soc. Perkin Trans. I 1984, 1021-1026; doi:10.1039/P19840001021.

22. Namikoshi, M.; Negishi, R.; Nagai, H.; Dimitrenok, M.; Kobayashi, H. Three new chlorine containing antibiotics from a marine-derived fungus Aspergillus ostianus collected in Pohnei. J. Antibot. 2003, 56, 755-761.

23. Sy, A.A.; Swenson, D.C.; Gloer, J.B.; Wicklow, D.T. Botryolides A-E, decarestrictine analogues from a fungicolous Botryotrichum sp. (NRRL 38180). J. Nat. Prod. 2008, 71, 415-419.

24. Buchanan, M.; Hashimoto, T.; Takaoka, S.; Asakawa, Y. (+)-Osmundalactone, $\gamma$-lactones and spiromentins from the fungus Paxillus atrotomentosus. Phytochemistry 1995, 40, 1251-1257.

25. Franck, X.; Araujo, M.E.V.; Jullian, J.-C.; Hocquemiller, R.; Figadère, B. Synthesis and structure determination of iso-cladospolide B. Tetrahedron Lett. 2001, 42, 2801-2803.

26. Uchida, I.; Kuriyama, K. The $\pi$ - $\pi^{*}$ circular dichroism of $\alpha, \beta$-unsaturated $\gamma$-lactones. Tetrahedron Lett. 1974, 15, 3761-3764.

27. Gawronski, J.K.; Oeveren, A.V.; Deen, H.V.D.; Leung, C.W.; Feringa, B.L. Simple circular dicroic method for the determination of absolute configuration of 5 -substitutaed $2(5 H)$-furanones. J. Org. Chem. 1996, 61, 1513-1515.

28. Beecham, A.F. The CD of $\alpha, \beta$-unsaturated $\gamma$-lactones. Tetrahedron 1972, 28, 5543-5554.

29. Lee, C.-L.; Chang, F.-R.; Hsieh, P.-W.; Chiang, M.-Y.; Wu, C.-C.; Huang, Z.-Y.; Lan, Y.-H.; Chen, M.; Lee, K.-H.; Yen, H.-F.; et al. Cytotoxic ent-abietane diterpenes from Gelonium aequoreum. Phytochemistry 2008, 69, 276-287.

30. Dale, J.A.; Mosher, H.S. Nuclear magnetic resonance enantiomer regents. Configurational correlations via nuclear magnetic resonance chemical shifts of diastereomeric mandelate, $O$-methylmandelate, and $\alpha$-methoxy- $\alpha$-trifluoromethylphenylacetate (MTPA) esters. J. Am. Chem. Soc. 1973, 95, 512-519.

31. Ohtani, I.; Kusumi, T.; Kashman, Y.; Kakisawa, H. High-field FT NMR application of Mosher's method. The absolute configurations of marine terpenoids. J. Am. Chem. Soc. 1991, 113, 4092-4096.

32. Jarvis, B.B.; Stahly, G.P.; Pavanasasivam, G.; Midiwo, J.O.; DeSilva, T.; Holmlund, C.E.; Mazzola, E.P.; Geoghegan, R.F., Jr. Isolation and characterization of the trichoverroids and new roridins and verrucarins. J. Org. Chem. 1982, 47, 1117-1124.

33. Jarvis, B.B.; Comezoglu, S.N.; Rao, M.M.; Pena, N.B. Isolation of macrocyclic trichothecenes from a large-scale extract of Baccharis megapotamica. J. Org. Chem. 1987, 52, 45-56.

34. Takeshita, M.; Sato, T. Synthesis of optically active 1-phenyl-1,2-propanediol by use of Baker's yeast. Chem. Pharm. Bull. 1989, 37, 1085-1086.

35. Ayer, W.A.; Trifonov, L.S. Metabolites of Peniophora polygonia, part 2. Some aromatic compounds. J. Nat. Prod. 1993, 56, 85-89.

36. Jarvis, B.B.; Wang, S.; Ammon, H.L. Trichoverroid stereoisomers. J. Nat. Prod. 1996, 59, 254-261.

37. Bari, L.D.; Pescitelli, G.; Pratelli, C.; Pini, D.; Salvadori, P. Determination of absolute configuration of acyclic 1,2-diols with $\mathrm{Mo}_{2}(\mathrm{OAc})_{4}$. 1. Snatzke's method revisited. J. Org. Chem. 2001, 66, 4819-4825.

38. Frelek, J.; Ruśkowska, P.; Suszczyńska, A.; Szewczyk, K.; Osuch, A.; Jarosz, S.; Jagodziński, J. Configurational assignment of sugar erythro-1,2-diols from their electronic circular dichroism spectra with dimolybdenum tetraacetate. Tetrahedron Asymmetry 2008, 19, 1709-1713. 
39. Xia, M.-W.; Cui, C.-B.; Li, C.-W.; Wu, C.-J. Three new and eleven known unusual C25 steroids: Activated production of silent metabolites in a marine-derived fungus by chemical mutagenesis strategy using diethyl sulphate. Mar. Drugs 2014, 12, 1545-1568.

40. Zhang, G.J. Studies on the Meroterpenoidal Constituents from Two Marine-Derived Fungal Strains. Ph. D. Thesis, Ocean University of China, Qingdao, China, June 2011.

41. Staunton, J.; Sutkowski, A.C. Biosynthesis of aspyrone, a metabolite of Aspergillus melleus: Advanced precursor studies to identify the product of the polyketide synthesis. J. Chem. Soc. Chem. Commun. 1991, 1108-1110; doi:10.1039/C39910001108.

42. Staunton, J.; Sutkowski, A.C. The polyketide synthase (PKS) of aspyrone biosynthesis evidence: Evidence for the enzyme bound intermediates from incorporation studies with $N$-acetylcysteamine thioesters in intact cells of Aspergillus melleus. J. Chem. Soc. Chem. Commun. 1991, 1110-1112; doi:10.1039/C39910001110.

43. Jacobs, A.; Staunton, J.; Sutkowski, A.C. Aspyrone biosynthesis in Aspergillus melleus: Identification of the intermediates formed on the polyketide synthase (PKS) in the first chain extension cycle leading to crotonate. J. Chem. Soc. Chem. Commun. 1991, 1113-1114; doi:10.1039/C39910001113.

44. Brereton, R.; Garson, M.; Staunton, J. Biosynthesis of fungal metabolites: Asperlactone and its relationship to other metabolites of Aspergillus melleus. J. Chem. Soc. Perkin Trans. I 1984, 1027-1033; doi:10.1039/P19840001027.

45. Ahmed, S.A.; Simpson, T.J.; Staunton, J.; Sutkowski, A.C.; Trimble, L.A.; Vederas, J.C. Biosynthesis of aspyrone and asperlactone, petaketide metabolites of Aspergillus melleus. Incorporation studies with $\left[1-1^{3} \mathrm{C},{ }^{18} \mathrm{O}_{2}\right]$ acetate and ${ }^{18} \mathrm{O}_{2}$ gas. J. Chem. Soc. Chem. Commun. 1985, 1685-1687.

46. Staunton, J.; Sutkowski, A.C. ${ }^{17} \mathrm{O}$ NMR biosynthetic studies: Aspyrone, asperlactone and isoasperlactone, metabolites of Aspergillus melleus. J. Chem. Soc. Chem. Commun. 1991, 1106-1108; doi:10.1039/C39910001106.

47. Fuchser, J.; Thiericke, R.; Zeeck, A. Biosynthesis of aspinonene, a branched pnetaketide produced by Aspergillus ochraceus, related to aspyrone. J. Chem. Soc. Perkin Trans. I 1995, 1663-1666; doi:10.1039/P19950001663.

48. Balcells, M.; Canela, R.; Coll, J.; Sanchís, V.; Torres, M. Effect of fungal metabolites and some derivatives against Tribolium castaneum (Herbst) and Nezara viridula (L.). Pesitic. Sci. 1995, 45, 319-323.

49. Kimura, Y.; Nakahara, S.; Fujioka, S. Aspyrone, a nematicidal compound isolated from the fungus, Aspergillus melleus. Biosci. Biotech. Biochem. 1996, 60, 1375-1376.

50. Torres, M.; Balcells, M.; Sala, N.; Sanchís, V.; Canela, R. Bactericidal and fungicidal activity of Aspergillus ochraceus metabolites and some derivatives. Pesitic. Sci. 1998, 53, 9-14.

51. Zhang, D.; Yang, X.; Kang, J.S.; Choi, H.D.; Son, B.H. Chlorohydroaspyrones A and B, antibacterial aspyrone derivatives from the marine-derived fungus Exophiala sp. J. Nat. Prod. 2008, 71, 1458-1460. 
52. Wu, C.-J.; Li, C.-W.; Cui, C.-B. Seven new and two known lipopeptides as well as five known polyketides: The activated production of silent metabolites in a marine-derived fungus by chemical mutagenesis strategy using diethyl sulphate. Mar. Drugs 2014, 12, 1815-1838.

(C) 2014 by the authors; licensee MDPI, Basel, Switzerland. This article is an open access article distributed under the terms and conditions of the Creative Commons Attribution license (http://creativecommons.org/licenses/by/3.0/). 